\title{
Palaeodrainage systems at the basal unconformity of the Bohemian Cretaceous Basin: roles of inherited fault systems and basement lithology during the onset of basin filling
}

\author{
DAVID ULIČNÝ, LENKA ŠPIČÁKOVÁ, RADOMÍR GRYGAR, MARCELA SVOBODOVÁ, STANISLAV ČECH \\ \& JIŘí LAURIN
}

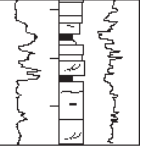

\begin{abstract}
This study presents a synthesis of currently available data on the distribution of Cenomanian-age palaeodrainage systems in the Bohemian Cretaceous Basin, filled by fluvial and estuarine strata, and an interpretation of their relationships to the basement units and fault systems. Much of the progress, compared to previous studies, was made possible by a recent basin-scale evaluation of Cenomanian genetic sequence stratigraphy. Several local palaeodrainage systems developed in the basin, separated by drainage divides of local importance and one major divide - the Holice-Nové Město Palaeohigh - which separated the drainage basins of the Tethyan and Boreal palaeogeographic realms. The locations and directions of palaeovalleys were strongly controlled by the positions of inherited Variscan basement fault zones, whereas the bedrock lithology had the subordinate effect of narrowing or broadening valleys on more vs. less resistant substratum, respectively. The intrabasinal part of the palaeodrainage network followed the slopes toward the Labe (Elbe) System faults and was strongly dominated by the conjugate, NNE-trending, Jizera System faults and fractures. Outlet streams - ultimate trunk streams that drained the basin area - are interpreted to have followed the Lužice Fault Zone toward the Boreal province to the Northwest, and the Železné hory Fault Zone toward the Tethyan province to the Southeast. At both the northwestern and southeastern ends of the Bohemian Cretaceous Basin, shallow-marine or estuarine conditions are proven to have existed during the early Cenomanian. Direct evidence for syn-depositional subsidence during the early to mid-Cenomanian, fluvial to estuarine phase is very rare, and the onset of deposition by fluvial backfilling of the palaeodrainage systems was driven mainly by the long-term rise in global sea level. Subtle surface warping, mostly without detectable discrete faulting, is inferred to have been a response to the onset of the palaeostress regime that later, with further stress accumulation, led to subsidence in fault-bounded depocentres of the Bohemian Cretaceous Basin and uplift of new source areas. $\bullet$ Key words: palaeodrainage, Cenomanian unconformity, Bohemian Massif, Elbe Zone, sequence stratigraphy.
\end{abstract}

UliČNÝ, D., ŠPIČÁKOVÁ, L., GrYGAR, R., SVObOdOVÁ, M., ČECH, S. \& LAURIN, J. 2009. Palaeodrainage systems at the basal unconformity of the Bohemian Cretaceous Basin: roles of inherited fault systems and basement lithology during the onset of basin filling. Bulletin of Geosciences 84(4), 577-610 (15 figures). Czech Geological Survey, Prague. ISSN 1214-1119. Manuscript received February 27, 2009; accepted in revised form July 7, 2009; published online October 5, 2009; issued December 31, 2009.

David Uličný, Institute of Geophysics, Academy of Sciences of the Czech Republic, v. v. i., Boční II/1401, 14131 Praha 4, Czech Republic; ulicny@ig.cas.cz.For co-authors'affiliations see p. 605.

Palaeodrainage systems develop on subaerial unconformity surfaces on all temporal scales, from geologically instantaneous through short-term cycles such as climate-driven glacio-eustatic changes, to major cycles of continental encroachment. The location, dimensions, morphological patterns, and longitudinal profiles of a palaeodrainage are the result of a multitude of factors, of which the structural fabric and lithology of the bedrock are clearly the leading ones (Howard 1967, Schumm \& Ethridge 1994). Active tectonic deformation on a local to regional scale, either closely pre-dating, or coeval with the palaeodrainage filling, can significantly modify the record of the palaeodrainage on the unconformity (Holbrook \& Schumm 1999). The key to understanding the palaeodrainage pattern is the study of its earliest infill (e.g., Andresen 1962, Siever 1951) which, in case of unconformities of long history, can reveal very complex palaeotopography arrays (e.g., Leckie 2008).

The existence of a palaeorelief underlying the strata of the Bohemian Cretaceous Basin (BCB; Fig. 1) and filled initially by fluvial deposits has been known since the early 


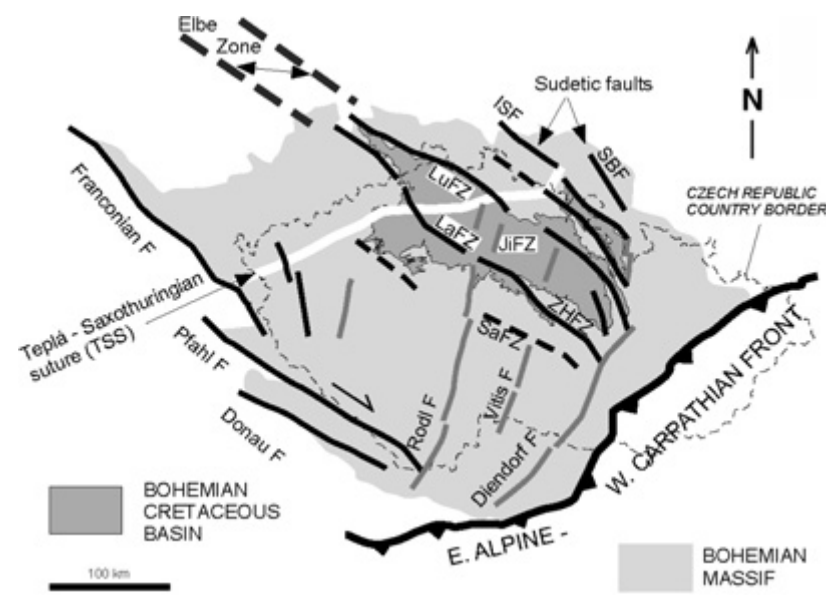

Figure 1. Sketch map of the Bohemian Cretaceous Basin and the main Variscan basement structures of the Bohemian Massif: structures of the the Elbe Zone, Bavarian Fault Zone and the most important faults in the Sudetes in black, Jizera Fault Group in dark grey, and the Teplá-Saxothuringian suture in white. Abbreviations: F - fault, LuFZ - Lužice Fault Zone, LaFZ - Labe Fault Zone, ZHFZ - Železné hory Fault Zone, SaFZ - Sázava Fault Zone, JiFZ - Jizera Fault Zone, ISF - Intra-Sudetic Fault, SBF - Sudetic Border Fault.

studies of the BCB (Krejčí 1865, Frič 1869, B. Zahálka 1911). This palaeorelief developed within a major unconformity that separates strata of Cenomanian age ( $\mathrm{ca}$ 99-93.5 Ma) from the underlying Variscan basement of the Bohemian Massif and from post-orogenic sedimentary and volcanic infills of basins of Late Palaeozoic to Triassic and, locally, Jurassic age (e.g. Eliáš 1981, S. Voigt et al. 2008). The base-Cretaceous unconformity is thus a composite, polyhistory surface, over much of its extent marked by palaeoweathering zones up to several tens of metres thick (e.g., Slavík 1922, Kamarád \& Malkovský 1956, Vachtl 1950, Vachtl et al. 1968, Störr et al. 1978, Klein et al. 1979). Locally, palaeokarst is developed on Palaeozoic and Jurassic carbonate substratum (Bosák 1995 and references therein). This surface records a period of planation and intense weathering in the Bohemian Massif, lasting for much of the Mesozoic, with a significant planation reached already prior to the Callovian transgression (Koutek 1927). Because the last pre-Cenomanian depositional episode in the Bohemian Massif occurred in the Jurassic (Callovian-Kimmeridgian deposition arguably covering a similar area as the Cretaceous basin; $c f$. Eliáš 1981 and Hanzlíková \& Bosák 1977), the minimum time gap represented by the unconformity is ca $55 \mathrm{Myr}$ ( $c f$. Ogg et al. 2004).

Early interpretations of palaeotopography and related Cenomanian drainage patterns were based on isolated outcrops and local boreholes (e.g., Matějka 1921). Intense drilling activity between the 1950s and 1970s resulted in the first basin-scale maps of the extent of the so-called "freshwater Cenomanian" (Klein in Svoboda et al. 1964, p. 281, and, later, Müller in Malkovský et al. 1974). In these maps, broad areas of presumed non-marine deposi- tion commonly included facies of estuarine to coastal origin, occurring partly beyond palaeovalleys. A refined version of the map by Malkovský et al. (1974), including inferred palaeoflow directions (Klein et al. 1979, T. Voigt 1996; Fig. 2), that has, until recently, been the only published basin-scale map of the palaeodrainage pattern, although some local- to regional-scale studies, using extensive borehole datasets, produced more detail on individual parts of the basin (Vajdík \& Vybíral 1973, Vajdík et al. 1978, Valečka 1979, Rutšek \& Kučera 1995, Uličný \& Špičáková 1996, Špičáková 1999, Kanta 2000). Facies analysis of some fluvial to estuarine palaeovalley fills (e.g., Uličný \& Špičáková 1996) found no evidence for extensive lakes or interior drainage, which indicated that the interpretation of apparently isolated depressions of "freshwater Cenomanian" in the early maps was an artifact of incomplete data coverage and facies interpretation problems. Uličný \& Čech (in S. Voigt et al. 2008) pointed out some relationships between the palaeodrainage systems, palaeohighs of the mid-Cenomanian relief, and some structural elements of the basement, but an up-to-date summary based on all currently available subsurface data, has been missing. A detailed identification of the location and nature of throughgoing drainage at the sub-Cretaceous unconformity thus remains one of the outstanding problems in understanding the evolution of the BCB. Its importance is underlined by the economic significance of the palaeovalley fills: refractory clays have been quarried from non-marine Cenomanian strata for centuries (e.g., Vachtl 1950, 1962; Soukup 1954; Vachtl et al. 1968); significant uranium accumulations exist locally (T. Voigt 1998), and Cenomanian palaeovalleys are hydrogeologically important as parts of the Cenomanian aquifer system (Herčík et al. 1999).

This study focuses on mapping of the distribution of palaeodrainage systems (PDSs) in the entire BCB and interpreting their relationships to the basement units and fault systems, based on a recent basin-scale evaluation of Cenomanian stratigraphy. The facies and stratigraphy of the Cenomanian are discussed here only to the extent necessary to explain the methodology and illustrate the basin-scale palaeodrainage infill patterns. Detailed sequence-stratigraphic and palaeontological aspects are being prepared for publication elsewhere.

\section{Approach - data, methods}

The main issues that this paper aims to address are the following:

- what was the role of structural elements and lithological properties of the basement in creating the Cenomanian palaeotopography?

- is there evidence for involvement of active tectonics in shaping the palaeodrainage network? 


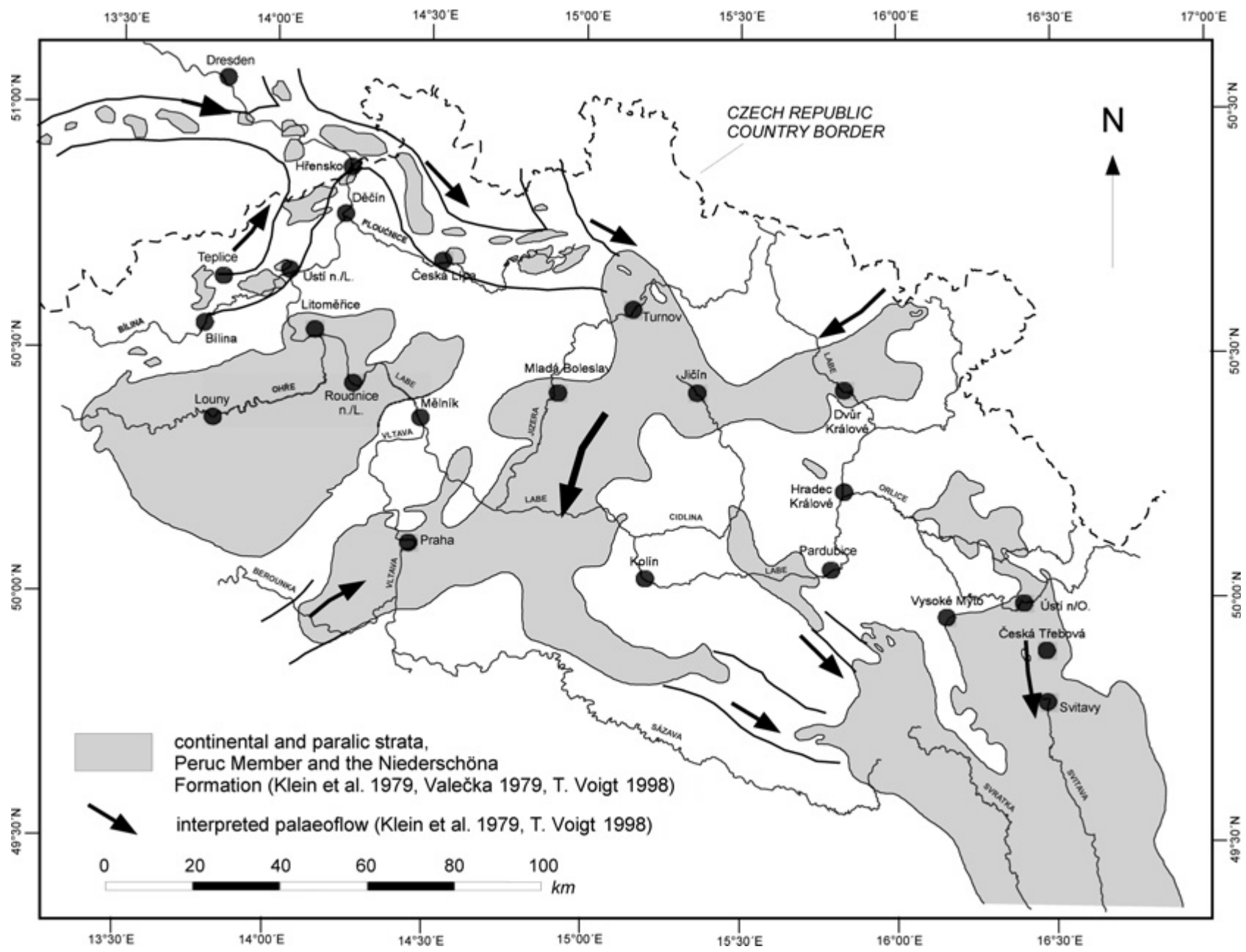

Figure 2. A compilation of earlier interpretations of the extent of the "freshwater Cenomanian" strata and interpreted palaeoflow directions in the palaeodrainage system, following T. Voigt (1998), based mostly on Klein et al. (1979).

- was the entire basin area drained toward the Tethys as suggested by the maps of Klein et al. (1979) or T. Voigt (1998), or toward the Boreal region as well?

- what was the earliest age of palaeodrainage infills, and what was the range of diachroneity from the earliest to latest valley fills?

- was the onset of filling of the palaeovalleys triggered exclusively by the Cenomanian sea-level rise, or at least in some cases, by localized subsidence ( $c f$. Valečka \& Skoček 1991)?

In order to contribute to answering the above questions, this paper builds on a basin-scale evaluation of the distribution, size, relationship to basement structure, and generalized infill history of the PDSs within the BCB basal unconformity. The main data base is represented by 2,630 archive records of boreholes that penetrated under the base of the Cenomanian. Almost all of the boreholes, drilled mostly between the 1950s and 1980s for various purposes, were cored and the data include digitized wireline logs, descriptions of core lithology, and, where available, archive core samples.
The density of borehole data varies strongly among regions, with the most extensive data coverage (locally a borehole grid of $100 \times 100 \mathrm{~m}$ ) in the area of uranium exploration and extraction in the 1960s-1980s in the Ralsko area (northern part of the basin, Fig. 3), and in the area of refractory clay exploration in the southeastern part of the basin. However,in some regions borehole spacing is as wide as $10 \mathrm{~km}$.

Sedimentological and sequence-stratigraphic interpretations of the subsurface data were corroborated by analysis of lithofacies, palaeocurrents, and depositional geometries in outcrops (e.g., Uličný et al. 1997a, Špičáková 1999, Kanta 2000, Uličný et al. 2004), with the aid of outcrop gamma-ray profiling correlated to well logs. Biostratigraphic dating was made possible by correlation of macroand micropalaeontological data between outcrops and cores. A new genetic sequence-stratigraphic framework was erected, based on a grid of basin-scale cross-sections. Isopach maps and palaeogeographic maps were constructed for the entire Cenomanian, as well as for selected time-slices. Heavy-mineral data, both archive and obtained 


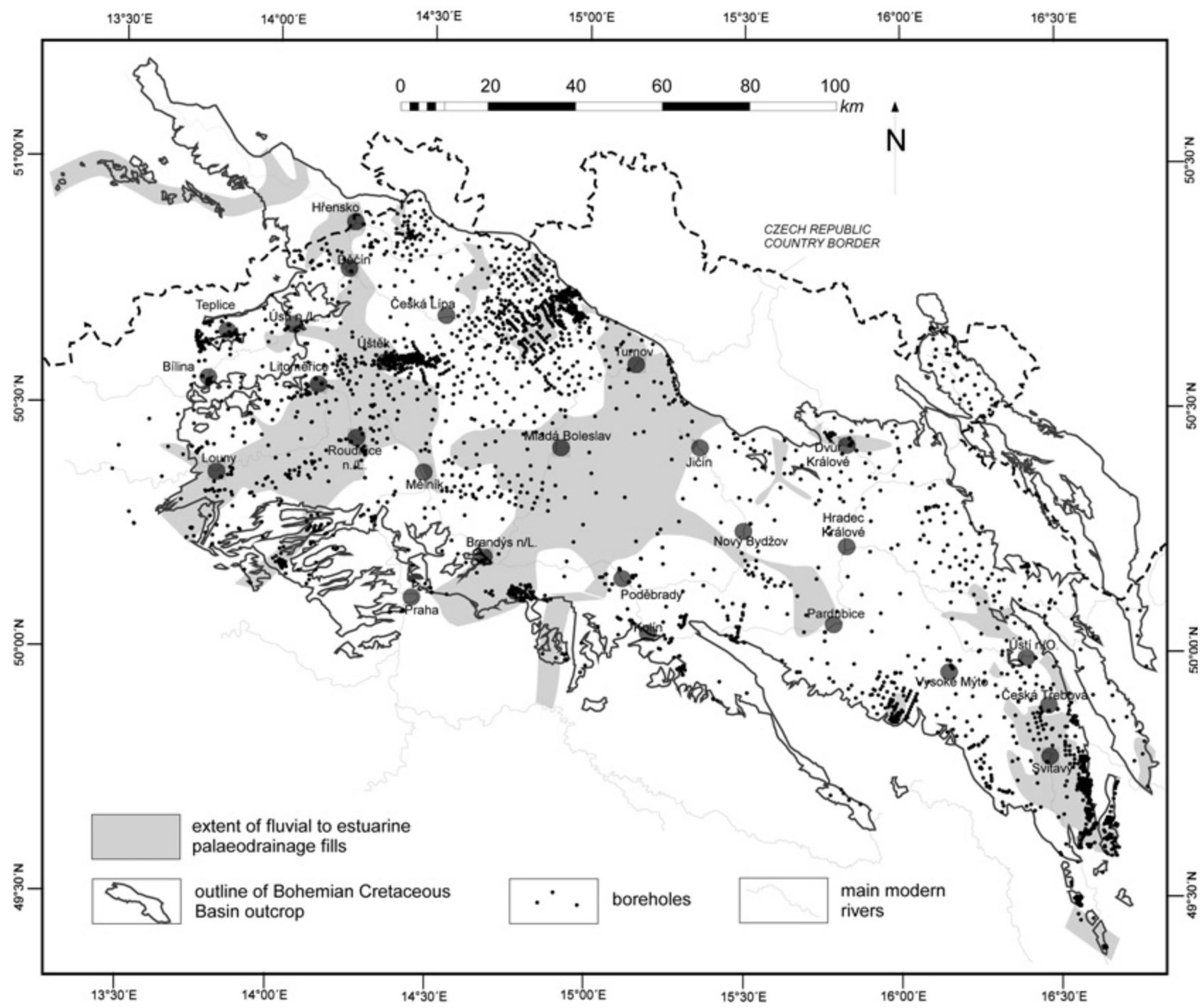

Figure 3. Borehole data coverage of the Bohemian Cretaceous Basin used in this study, overlain above the extent of fluvial to estuarine fills of the palaeodrainage systems as defined in this study. All 2,630 boreholes shown reached the basement.

by this study, were used locally to supplement other data on drainage directions. Where possible, historical palaeogeographic names, especially of palaeohighs and source areas, were followed, but palaeodrainage systems and individual palaeovalleys are mostly either newly defined, or follow Špičáková (1999).

To interpret the relationships between palaeodrainage patterns and the basement lithology and structure, a palaeogeological map showing the base-Cretaceous subcrop was compiled from a number of archive sources (see caption in Fig. 4). A new structural map of the basin was compiled based on evaluation of a digital elevation model, maps of Bouguer anomalies and horizontal gravity gradients, available seismic reflection profiles and surface geological maps, and supplemented by field documentation of mesoscale brittle structures of both pre- and post-Cretaceous deformation phases.

\section{Basement units and main fault systems}

The BCB extends for more than $300 \mathrm{~km}$ in length and $100 \mathrm{~km}$ in preserved width across a large part of the northern Bohemian Massif (Fig. 1). The basement of the BCB (Fig. 4) involves most of the zones of the Variscan orogen (Kossmat 1927, Matte et al. 1990, among many others; see Kroner et al. 2008, and Cháb et al. 2008 for recent compilations). The Saxothuringian Zone, dominated by high-pressure metamorphics in the northwestern part of the region, is separated by a generally WSW-ENE-trending suture from the neighbouring Teplá-Barrandian Zone (Fig. 5). The Teplá-Barrandian Zone comprises mostly non-metamorphosed sediments and low-grade metasediments, with the metamorphic grade increasing towards the suture (e.g., Matte et al. 1990, Beard et al. 1995, Franke et al. 2000, Dörr et al. 2002). Further east and southeast, the 
high-grade metamorphics of the Moldanubian Zone and its likely equivalent in the Lugian Zone to the N-NE (Suess 1912; cf. Schulmann et al. 2008) represent the Variscan orogenic root (Fig. 4). Their contact with the Teplá-Barrandian rocks is obscured by the intrusions of the Central Bohemian and Nasavrky Plutonic complexes of Devonian (370 Ma) to early Carboniferous age ( ca 350-340 Ma; e.g., Košler et al. 1993, Žák et al. 2005). In the easternmost extremity of the basin region, the basement is represented by the MoravoSilesian Unit and the Brunovistulian (or Brunnia) domain, both overthrust by the Moldanubian rocks (Fig. 4; Suess 1912, 1925; Schulmann et al. 2009, and references therein). Relicts of the Cretaceous basin fill in the Brno area indicate that prior to Cenozoic erosion, the Cretaceous deposits covered these units much more extensively than at present (e.g., Stráník et al. 1996, and references therein).

The most important post-orogenic unit occurring in the $\mathrm{BCB}$ substratum is represented by the clastic and volcanic infills of a suite of Carboniferous-Permian extensional and transtensional basins (Jindřich 1971, Malkovský 1987). Most of these basins formed about $310 \mathrm{Ma}$ (Lippolt et al. 1986) by the extensional collapse of orogenically thickened crust along the inherited crustal inhomogeneity of the Teplá-Saxothuringian suture zone, similar to post-orogenic basins elsewhere throughout the Variscan orogen (e.g., Malavieille et al. 1990). Some pull-apart basins of this age formed along major shear zones of NW and NNE strike (Pašek \& Urban 1990, Opluštil in McCann et al. 2008).

Triassic clastics and Jurassic carbonates are represented by minor relicts under the Cretaceous cover (Malkovský et al. 1974, Eliáš 1981 and references therein). In the Saxonian part of the BCB, lithoclasts in the lower parts of the Cretaceous basin fill indicate that prior to significant uplift and erosion during the Cretaceous, Jurassic strata of appreciable thickness existed in the Lužice (Lausitz) region (T. Voigt 1994).

The axis of the BCB follows the southeastern end of the WNW-ESE-striking zone of intense brittle faulting in the northern half of the Bohemian Massif (Fig. 1) that belongs to the SE part of the Elbe Fault System in the broad sense of Scheck et al. (2002). In this paper, the term "Elbe Zone" is used for the part of the Elbe Fault System to the SE of Dresden, striking generally N120E, and widening southeastward into a belt of distributed deformation in the upper crust, $c a$. $100 \mathrm{~km}$ across, which splits into more discrete faulted domains, as shown in Figs 4-6. This concept is different from the definition of the "Elbe Fracture" or "Elbe Fault" as a narrow, mainly ductile shear zone in Arthaud \& Matte (1977), Matte et al. (1990), or as used by Mattern (1996) in his concept of the "Elbe Zone".

In this paper, four main fault groups are recognized (Figs 1,6). Numerous WNW-striking faults in the northern Bohemian Massif, representing the SE part of the Elbe Fault System sensu Scheck et al. (2002) are referred to as the Labe Fault Group (FG) here, in order to avoid confusion due to many concepts of the Elbe Zone. However, NW- to NNW-striking faults in the Sudetes, treated by Scheck et al. (2002) as part of the Elbe Fault System, are considered here as a separate group, the Sudetic FG (Figs 1, 6). NNE-striking faults are termed the Jizera FG, and faults of NE to ENE strike, parallel to the suture between the Saxothuringian and Teplá-Barrandian crustal blocks represent the Ohře FG. These four fault groups underwent multiple reactivations since the Palaeozoic and at present they show modest geodynamic activity (Špaček et al. 2006) and exert a strong influence on the modern topography, including drainage systems of major rivers in Bohemia ( $c f$. modern river courses in Fig. 6). Below, the main features of these fault groups are summarized.

\section{WNW- to NW-trending faults: the Labe and Sudetic fault groups}

In the $\mathrm{BCB}$, the southeastward divergence of the Elbe Zone in Saxony gives rise to two most prominent fault zones: the Lužice FZ (marking the northern edge of the BCB) and the Labe-Železné hory FZ (Figs 6, 7). The latter is conventionally divided into two separate parts - the Labe and Železné hory FZ, located, respectively, west and east of the junction with the NNE-striking Kouřim Fault.

Uličný et al. (2009) interpreted a number of NW-trending, overstepping, short fault segments, oriented N135E to N150E, as synthetic Riedel shears of the Lužice, Labe, and Železné hory FZ. These segments contributed to the formation of a densely faulted domain of distributed shearing. The Labe FZ shows bending from a WNW strike near the Labe-Jizera rivers confluence, to a nearly NNW strike in the northwestern part of the basin, where the zone is represented by an up to $25 \mathrm{~km}$ wide belt of densely spaced NW-SE faults, aligned with faults L4-L5 in Fig. 6.

In the easternmost part of the basin, many faults strike N160E to N170E, especially those defining the postdepositional, asymmetric horsts and half-grabens that formed during the Cenozoic inversion and are assumed to be parts of the Sudetic FG (Fig. 6). Their role during the Cretaceous deposition is, however, uncertain. To the northeast of the main body of the BCB fill, the Intra-Sudetic sub-basin and the Nysa Graben, bounded in part by faults of the Sudetic group, are considered external parts of the BCB sensu lato ( $c f$. Jerzykiewicz \& Wojewoda 1986, among others).

The onset of activity of the WNW to NW-striking dextral ductile shear zones in the Variscides is dated as Late Devonian-Viséan (e.g., Aleksandrowski et al. 1997, Matte et al. 1986), i.e., before the formation of the Late Carboniferous extensional basins. Later activity occurred at < $295 \mathrm{Ma}$, in late Stephanian to early Permian, with 


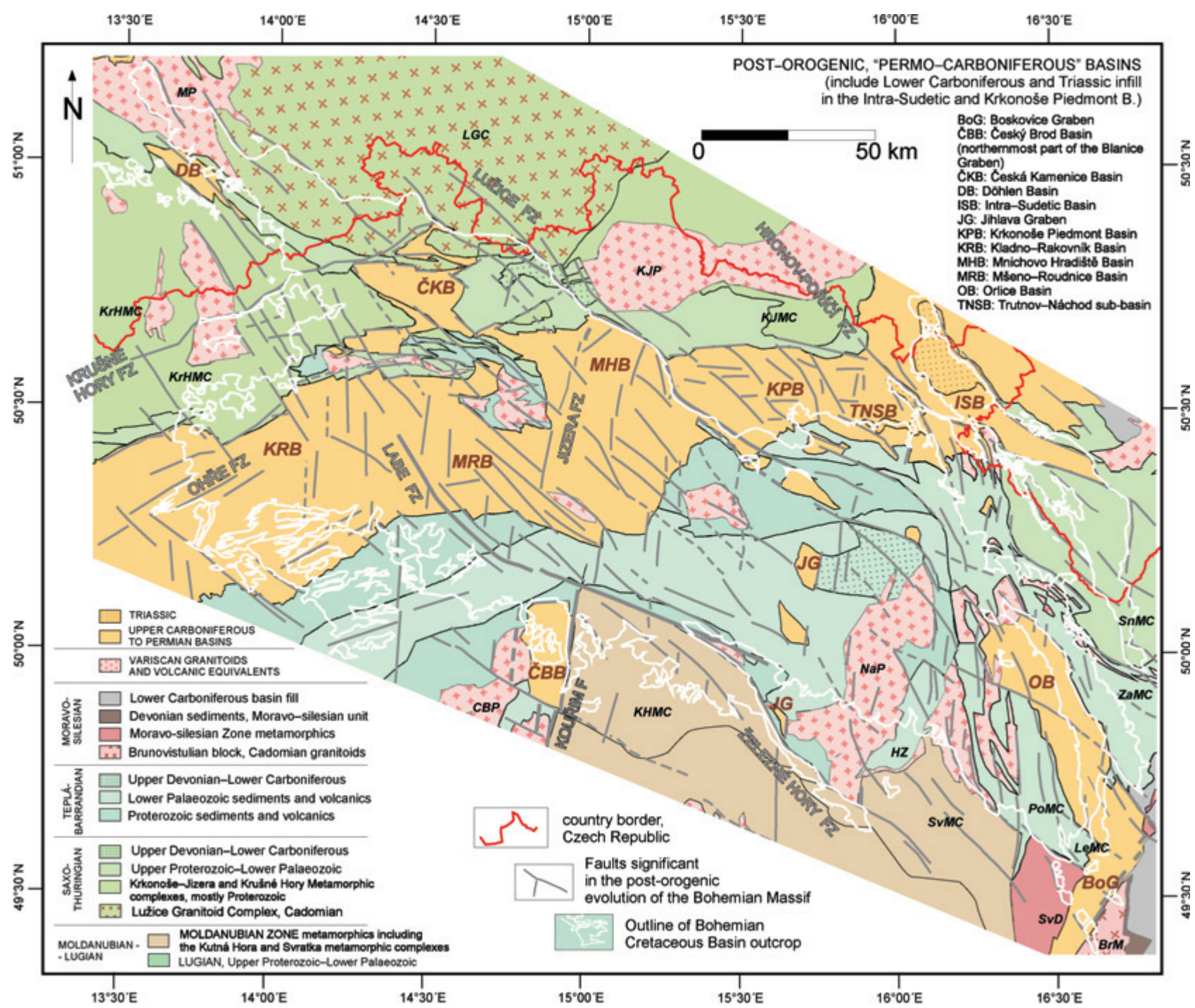

Figure 4. Simplified geological subcrop map of the basement of the Bohemian Cretaceous Basin. Compiled from the following sources: Cháb et al. (2007), Chaloupský (1973 and in Malkovský et al. 1974), Chudomel et al. (1983), Mlčoch (2001), Kumpera et al. (1986, 1988), Rutšek \& Kučera (1995), Pešek et al. (2001). Abbreviations used for regional metamorphic and igneous units: BrM - Brno Massif, CBP - Central Bohemian Plutonic Complex, HZ - Hlinsko Zone, KHMC - Kutná Hora Metamorphic Complex, KrHMC - Krušné hory Metamorphic Complex, KJMC - Krkonoše-Jizera Metamorphic Complex, KJP - Krkonoše-Jizera Pluton, LeMC - Letovice Metamorphic Complex, LGC - Lužice Granitoid Complex, MP - Meissen Pluton, $\mathrm{NaP}$ - Nasavrky Plutonic Complex, PoMC - Polička Metamorphic Complex, SnMC - Sněžník Metamorphic Complex, ZaMC - Zábřeh Metamorphic Complex, SvMC - Svratka Metamorphic Complex, SvD - Svratka Dome.

dextral motions interpreted by Pitra et al. (1999), and putative sinistral kinematics suggested by Mattern (2001). The Permian phase of dextral shearing has left a distinct record in the offset of parts of Carboniferous basin fills in Central Bohemia (see below). According to Uličný \& Čech (in S. Voigt et al. 2008) and Uličný et al. (2009), the Labe Group faults acted during the Cretaceous deposition as oblique-extensional faults with a minor dextral component of slip, and partitioned the area of overlap between the Lužice and Labe-Železné Hory FZ into individual sub-basins and source areas during the main phases of Cretaceous sedimentation (Fig. 1; e.g., Uličný et al. 2003a; Uličný \& Čech in S. Voigt et al. 2008). Both the Lužice and
Železné Hory FZ were transformed into high-angle reverse faults during the Late Cretaceous-Palaeogene inversion of the Alpine foreland (Ziegler 1990, Coubal 1990), which caused destruction of part of the depositional record most proximal to the faults.

\section{NNE-trending faults: the Jizera Fault Group}

NNE-directed fracture zones ( $c a$ N5E-N10E) accompany the Labe FG as the antithetic part of a conjugate fault set (cf. Brandmayr et al. 1995) and form a pervasive structural pattern in the entire $\mathrm{BCB}$ region (Figs 6, 7). Among the 


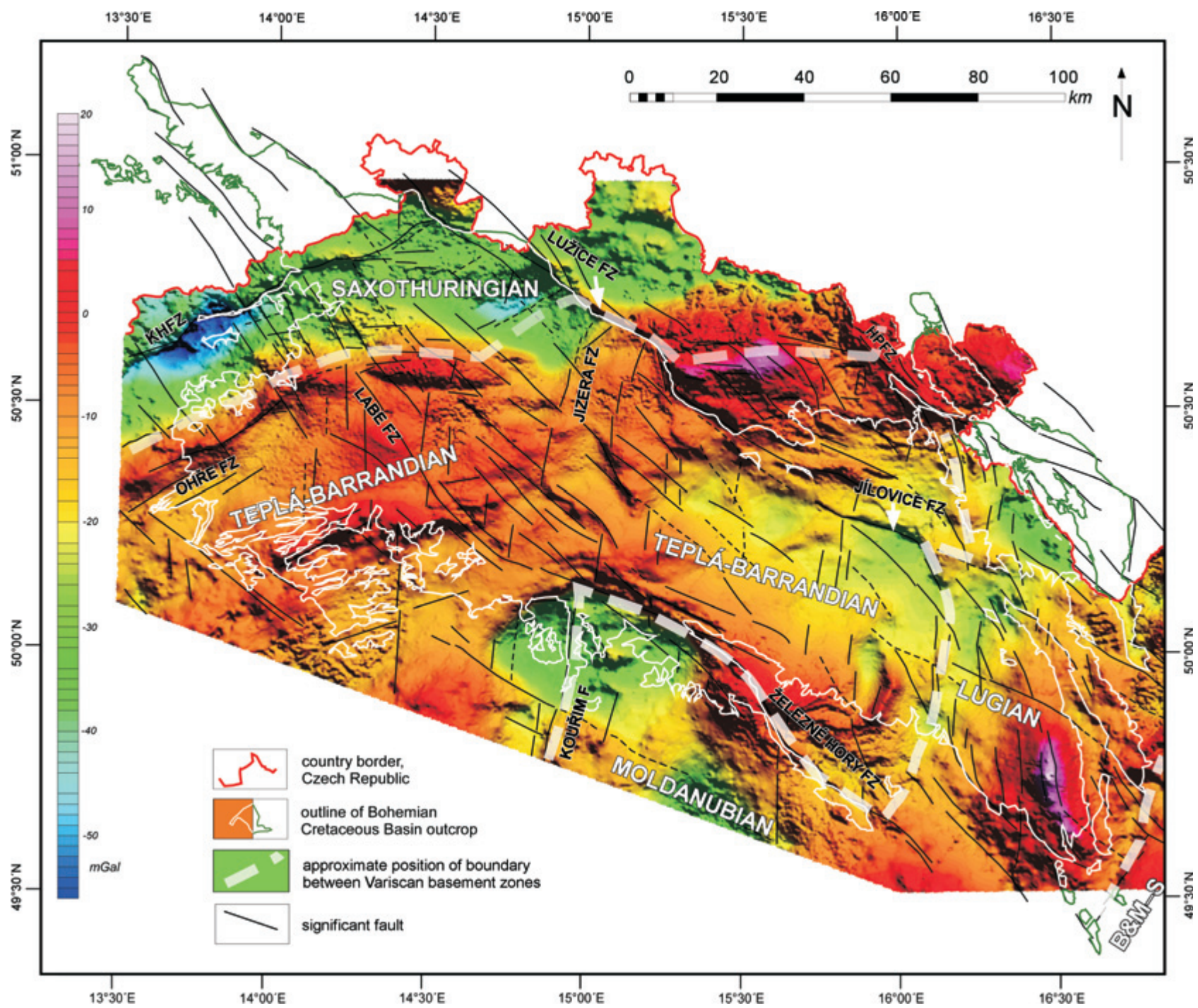

Figure 5. Map of complete Bouguer gravity anomalies, calculated using a reduction density of $2.3 \mathrm{~g} \mathrm{.} \mathrm{cm}^{-3}$, illuminated from N30E, inclination $55^{\circ}$. Main Variscan basement units and fault framework from Fig. 4 are shown for comparison. Abbreviations: KHFZ - Krušné Hory Fault Zone, B\&M-S - Brunovistulian and Moravo-Silesian unit, HPFZ - Hronov-Pořičí Fault Zone. Map acquired from Geofyzika, a.s., Brno, for project OG-9/02 of the Ministry of Environment of the Czech Republic (Uličný et al. 2004).

most prominent of these fault zones in the Bohemian Massif is the Rodl Shear Zone, passing into the Late Paleozoic Blanice Graben toward the North and interpreted as a major Variscan sinistral strike-slip zone (Fig. 1; Matte et al. 1990, Brandmayr et al. 1995). In its northern part it modifies the boundary between the Teplá-Barrandian and Moldanubian zones and can be traced, as a series of overstepping faults such as the Kourim Fault, up to the junction with the Labe FZ. Further north, similar faults are interpreted to form the eastern boundary of the Late Palaeozoic Mnichovo Hradiště Basin (Fig. 4).

Relicts of Upper Palaeozoic clastics under the Cretaceous cover in eastern Bohemia appear to lie in a northern extension of the putative Jihlava Graben that is aligned with the Vitis Fault further south (Brandmayr et al. 1995; Holub in Pešek et al. 2001). At depth, this major NNE-striking lineament coincides with the interpreted leading edge of the Brunia crustal segment underthrust beneath the Moldanubian Zone (Schulmann et al. 2008). Faults of the Boskovice Graben, although bent more to the NE in its northern part (J 11 in Fig. 6), are interpreted as a similar, sinistral shear zone forming, on the surface, the eastern border of the Moldanubian Zone (northern extension of the Diendorf Fault Zone, Brandmayr et al. 1995 and references therein). The Nasavrky Pluton, regarded as the eastern extension of the Central Bohemian Pluton (Schulmann et al. 2009), apparently dextrally translated along the Železné hory FZ, is also strongly affected by NNE-trending fault zones, as noted already by Chaloupský (1974). The same applies to the Lugian Zone meta- 
morphics to the east of the Nasavrky Pluton and the Hlinsko Zone (Fig. 4).

Extension followed by left-lateral strike slip on these NNE-SSW structures led to formation of long, narrow, pull-apart basin systems ("troughs" or "furrows" in Czech literature) during the latest Carboniferous and Permian (Pašek \& Urban 1990, Synek, unpublished data; Uličný et al. 2002). Mid-Cretaceous (Late Cenomanian and Turonian) activity of faults in this group was documented by Uličný et al. (2003b, 2009) from the central part of the basin (Jizera FZ, Fig. 5).

\section{NE and E-W-trending faults: the Ohře Fault Group}

The third component of the regional structural grain is named the Ohře Fault Group here because it parallels the Cenozoic Ohře (Eger) Graben. The graben runs across the Elbe Zone structures, parallel to the NE to ENE-trend of a major crustal boundary between the Saxothuringian and Teplá-Barrandian zones of the Variscan orogen that formed as the suture of the Saxothuringian ocean about $340 \mathrm{Ma}$ (Matte et al. 1990, Pitra et al. 1999, Konopásek \& Schulmann 2005). The trend of the Teplá-Saxothuringian suture is followed by the strike of folds and thrusts in strongly deformed Lower Palaeozoic basins of the Teplá-Barrandian Zone.

The belt of Late Palaeozoic extensional basins that formed along the Teplá-Saxothuringian suture (Figs 4, 5), shows several changes in strike as it crosses segments of the Elbe Zone. Between the Labe-Železné hory and the Lužice FZ its strike becomes nearly east-west, except in the vicinity of the Lužice FZ where some authors interpret it to roughly follow the NE-trending Stráž Fault (Fig. 6). Northeast of the Lužice FZ, the Ohře Group faults (and the suspected suture trace at depth) run almost E-W again, following the northern border of the Krkonoše Piedmont Basin and continuing further NE to the Sudetes on the Czech-Polish border ( $c f$. Mazur \& Aleksandrowski 2001, Franke \& Żelaźniewicz 2000). This feature is explained as a consequence of dextral shearing along the Labe FG, mainly during the Permian (Fig. 8; cf. Pitra et al. 1999). The E-W trend in the Krkonoše Piedmont Basin was interpreted by Uličný et al. (2002) as caused by Permian and, partly, Cretaceous dextral deformation of an originally NE-striking basin, along a rheologically weak crustal zone following the present-day Lužice FZ. Uličný (2005) suggested an analogous interpretation for the strongly deformed Roudnice Basin affected by mappable Riedel shears related to the Labe FZ. A probable result of this primarily Permian-age deformation is the nearly E-W trend of the Ǔšěk FZ and the borders of the Česká Kamenice Ba$\sin$ (Figs 4, 6).

Many structures of the Ohře FG were reactivated dur- ing the formation of the Cenozoic Ohře Graben and its Plio-Quaternary deformation (Ziegler \& Dèzes 2007, Rajchl et al. 2009) that gave rise to the topographically prominent Krušné hory FZ in NW Bohemia; the potential Cretaceous activity of these structures is, however, not well understood.

\section{The Peruc-Korycany Formation: record of the inception of basin filling}

\section{Age, depositional systems, and lithostratigraphy}

The earliest infill of the BCB is represented by a diverse suite of fluvial to shallow-marine facies of Cenomanian age (Fig. 9). The oldest proven age is Early Cenomanian (Meissen Fm. in Saxony, Fig. 10A, Tröger 2003, and the Blansko Graben in Moravia: Svobodová 1992, 1997; Svobodová \& Brenner 1999). Svobodová (1992) and Svobodová \& Brenner (1999) suggested a possible Albian age for the lowermost palaeovalley fill in the Blansko Graben, which remains unproven. On the Czech territory, the Cenomanian strata are jointly termed the Peruc-Korycany Formation (Čech et al. 1980; see references therein for the history of nomenclature). This dominantly clastic package overlies the sub-Cretaceous unconformity and is, in turn, overlain by a major transgressive surface that defines the Cenomanian-Turonian boundary (e.g. Valečka \& Skoček 1991; Uličný et al. 1997a, b; Čech et al. 2005). Nomenclature for the German part of the basin is summarized in Tröger (2003) and S. Voigt et al. (2008).

The prevailing pattern in the Cenomanian succession is a gradual marine flooding that culminated close to the Cenomanian-Turonian boundary and was punctuated by a number of high-frequency, small-scale, relative sea-level changes (e.g., Uličný \& Špičáková 1996). These relative sea-level changes caused rapid shifts in depositional environments along low-gradient slopes and marked palaeogeographic changes. A typical, complete vertical succession involves, from bottom to top, valley-filling, fluvial to estuarine deposits (the Peruc Member), overlain by coarser-grained, nearshore sandstones (the Korycany Member), capped, in turn, by fine-grained offshore deposits (informally named the Pecínov Member, Uličný et al. 1997b). Fig. 10 shows the "end-member" scenarios of the Cenomanian palaeogeography that correspond to the time of the onset of palaeovalley filling in the early to middle Cenomanian (Fig. 10A) and the late Cenomanian deposition in a shallow marine strait (Fig. 10B). The lithostratigraphic members of the Peruc-Korycany Fm. represent essentially facies associations (Houša 1991) that show marked diachroneity between individual parts of the basin (Fig. 11). 
David Uličný et al. • Palaeodrainage systems at the basal unconformity of the Bohemian Cretaceous Basin

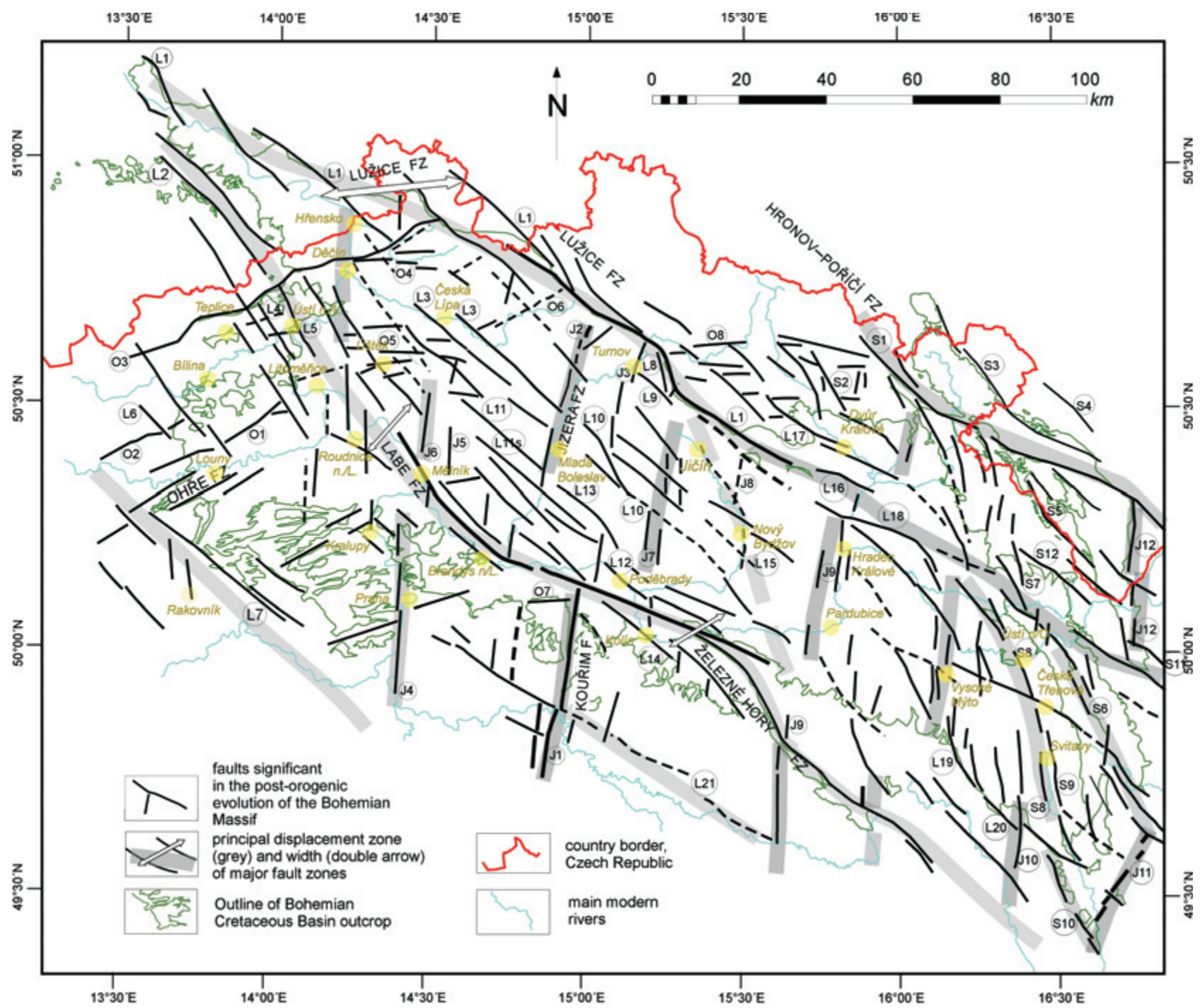

Figure 6. Map showing the principal faults and fault zones significant in the post-orogenic evolution of the Bohemian Massif. Most of the Oligo-Miocene faults in the Ohře Graben region are omitted for clarity. Thick grey lines indicate fault zones interpreted as important in the kinematics of the Bohemian Cretaceous Basin (cf. Uličný et al. 2009). The circled numbers refer to fault lines touching the circle in the map. Note: only the most important faults are illustrated that are considered to have been active during the post-orogenic evolution of the Bohemian Massif, in particular during the Mesozoic. Many faults, especially within the Bohemian Cretaceous Basin, remain unnamed. - Abbreviations: L - the Labe Fault Group: L1 - Lužice Fault Zone, L2 - Karsdorf Fault, L3 - Ploučnice Fault Zone (two overstepping strands), L4 - Žitenice Fault, L5 - Luční potok Fault, L6 - Chomutovka Fault Zone, L7 - Krušovice Fault Zone, L8 - Rovensko Fault, L9 - Libuňka Fault, L10 - Sukorady sub-basin marginal fault, L11n - Skalský potok Fault Zone North, L11s - Skalský potok Fault Zone - South, L12 - Poděbrady Fault, L13 - Luštěnice Fault, L14 - Kolín Fault, L15 - Mlékosrby Fault according to Valečka et al. (2003), L16 - Mlázovice Fault, L17 - Zvičina Fault, L18 - Jílovice Fault, L19 - Polička Fault, L20 - Lačnov Fault Zone, L21 - Sázava Fault Zone. - S - Sudetic Fault Group: S1 - Hronov-Poříčí Fault Zone, S2 - Pilníkov fault, S3 - Broumov Cliffs Fault, S4 - Intra-Sudetic Fault, S5 - Zieleniec Fault, S6 - Kyšperk Fault, S7 - Žamberk Fault, S8 - Semanín Fault, S9 - Orlice Graben western border faults, S10 - Blansko Graben border faults, S11 - Bušín Fault, S12 - Olešnice-Uhřínov Fault Zone. • O -the Ohře Fault Group: O1 - Ohře Fault Zone, O2 - Střezov Fault, O3 - Krušné hory Fault Zone, O4 - Děčín Fault Zone, O5 - Úštěk Fault Zone, O6 - Stráž Fault, O7 - Kounice Fault, O8 - Škodějov Fault. • J - the Jizera Fault Group: J1 - Kouřim fault and the Blanice Graben fault zone, J2 - Jizera Fault Zone - West, J3 - Jizera Fault Zone - East, J4 - Vltava Fault Zone, J5 - Kokořín Fault Zone, J6 - Liběchov Fault Zone, J7 - Eastern border faults, Mnichovo Hradiště Basin, J8 - Sobčice Fault, J9 - Jihlava Graben border faults, J10 - Svojanov shear zone, J11 - Boskovice Graben border faults, J12 - Nysa Graben, Eastern border faults.

The thickness of the Peruc-Korycany Fm. varies between zero and $120 \mathrm{~m}$. Palaeovalleys and long-lived palaeohighs are mostly well reflected in the isopachs of the entire Peruc-Korycany Fm. in many parts of the basin (Fig. 12). Especially in the proximity of the bounding faults, however, the total thickness of the Cenomanian is a combined result of (1) filling the pre-depositional topography (Fig. 10A) and (2) subsidence and infill of new depocentres that became established mainly during the late Cenomanian (Fig. 10B). Therefore, the isopach maxima do 


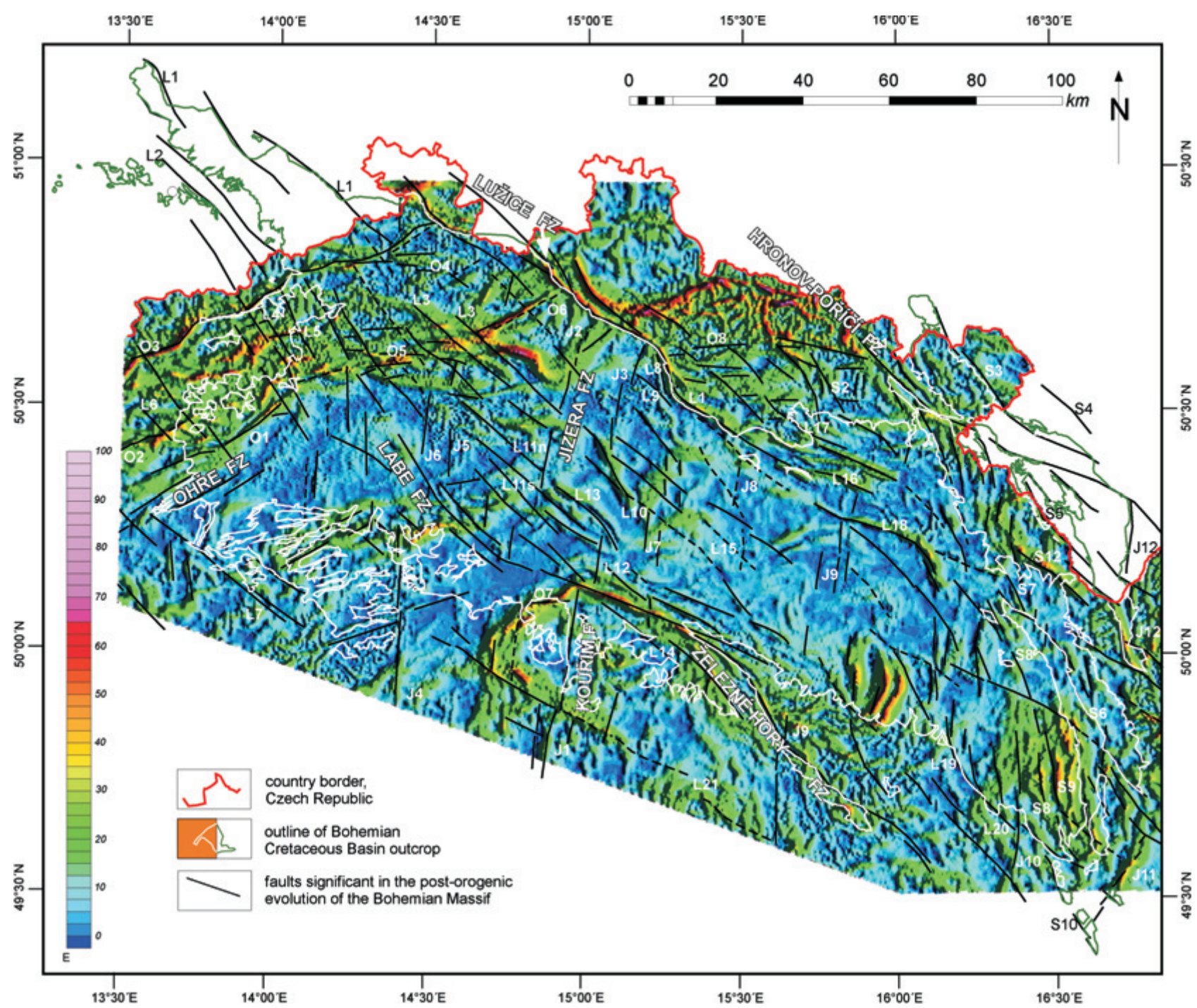

Figure 7. Map of horizontal gravity gradients, based on the complete Bouguer anomalies shown in Figure 5. Illumination from the East, inclination $40^{\circ}$. Map acquired from Geofyzika, a.s., Brno, for project OG-9/02 of the Ministry of Enviroment of the Czech Republic (see Uličný et al. 2004).

not always correlate with palaeodrainage axes. The directions of drainage of the palaeovalleys described below and in Figs 10-13 were not derived from thickness gradients of the entire Cenomanian, but are based mainly on interpretation and correlation of facies in a genetic sequence-stratigraphic framework (see below).

\section{Criteria for genetic sequence definition}

In order to map the basin filling in separate time steps and discriminate between filling of passive topography and deposition in active depocentres, the Cenomanian package had to be divided into distinct subunits using nearisochronous surfaces. Therefore, the lithostratigraphic nomenclature is not used in this paper, and instead, a genetic-stratigraphic subdivision ( $c f$. Galloway 1989) of the Bohemian Cenomanian, based on major transgressive surfaces and their nonmarine equivalents, was applied, following Špičáková \& Uličný (2001).

It is beyond the scope of this paper to deal with details of the sequence-stratigraphic aspects which will be published separately. However, because a genetic-stratigraphic correlation within the valley-filling stratal packages was used for interpreting the evolution of the valley-fill geometries and directions of drainage, the criteria used to define genetic sequences in the Cenomanian of Bohemia are briefly outlined below, and selected details are described in more depth in online Appendix 1 (available on www.geology.cz/bulletin).

Interpretation and correlation of transgressive surfaces in the paralic to shallow-marine strata is relatively straightforward, based on widely used criteria (Van Wagoner et al. 1988, Posamentier \& Allen 1999, and references 
therein; see Laurin \& Uličný 2004, Uličný et al. 2009, for application in the Turonian of Bohemia). Diagnosis of correlative surfaces in the updip non-marine strata is more difficult, however, and in a dataset lacking continuous exposure it requires application of certain conceptual assumptions about the factors controlling the linked depositional systems, such as base-level change vs. supply and water discharge (e.g., Martinsen et al. 1999, Plint et al. 2001). The abundance of well-log and core data in the study region made it possible to correlate the marine to paralic and non-marine facies, based on evaluation of well-log patterns, sedimentological criteria, macro- and microfossil content (palynology in particular), and trace fossils.

Although the application of the accommodation-supply concept to non-marine strata has conceptual limitations (Blum \& Törnqvist 2000), the correlations in the Bohemian Cenomanian permitted a scheme of non-marine surfaces and systems tracts, similar to that of Martinsen et al. (1999), to be established, with two main surface types. The first type, termed an expansion surface, following Martinsen et al. (1999), underlies stratal packages that show, in contrast to underlying strata, an increased proportion of floodplain strata, decreased amalgamation of sandy to gravelly channel-fill bodies and overall fining of grain size. Expansion surfaces are documented to onlap palaeovalley sides. In terms of stratal architecture, units overlying the expansion surfaces are characterized by sheet-like sandbodies encased in floodplain fines, interpreted as meandering river deposits, or by mudstones with isolated channel-fills and local splay sandstones, which are interpreted as anastomosing river sediments. Occurrence of marine microplankton above some expansion surfaces in fluvial strata, together with sedimentological indicators of tidal influence such as paired mud drapes or ichnotaxa indicative of a marine environment, link the expansion surfaces to transgressive surfaces in the marine to paralic realms ( $c f$. Uličný \& Špičáková 1996).

The second type, an unconformity surface, is characterized by an abrupt decrease in mud content indicated by well-logs and associated with erosion that is documented to be deeper than the typical channel depth in outcrop and displays a correlatable regional extent. Strata overlying the erosion surfaces are characterized by dominance of coarsegrained channel fills, laterally and vertically strongly interconnected. Strongly pedogenically modified intervals in floodplain strata are correlated to unconformity surfaces.

As illustrated in Appendix 1, the expansion surfaces are correlated with marine flooding surfaces and interpreted as caused by an acceleration of the rate of baselevel rise. Unconformity surfaces are analogous to the "Exxon-type" sequence boundaries - that is, surfaces caused by base-level falls with regional incision and slope rejuvenation. Because they can be defined with confi-
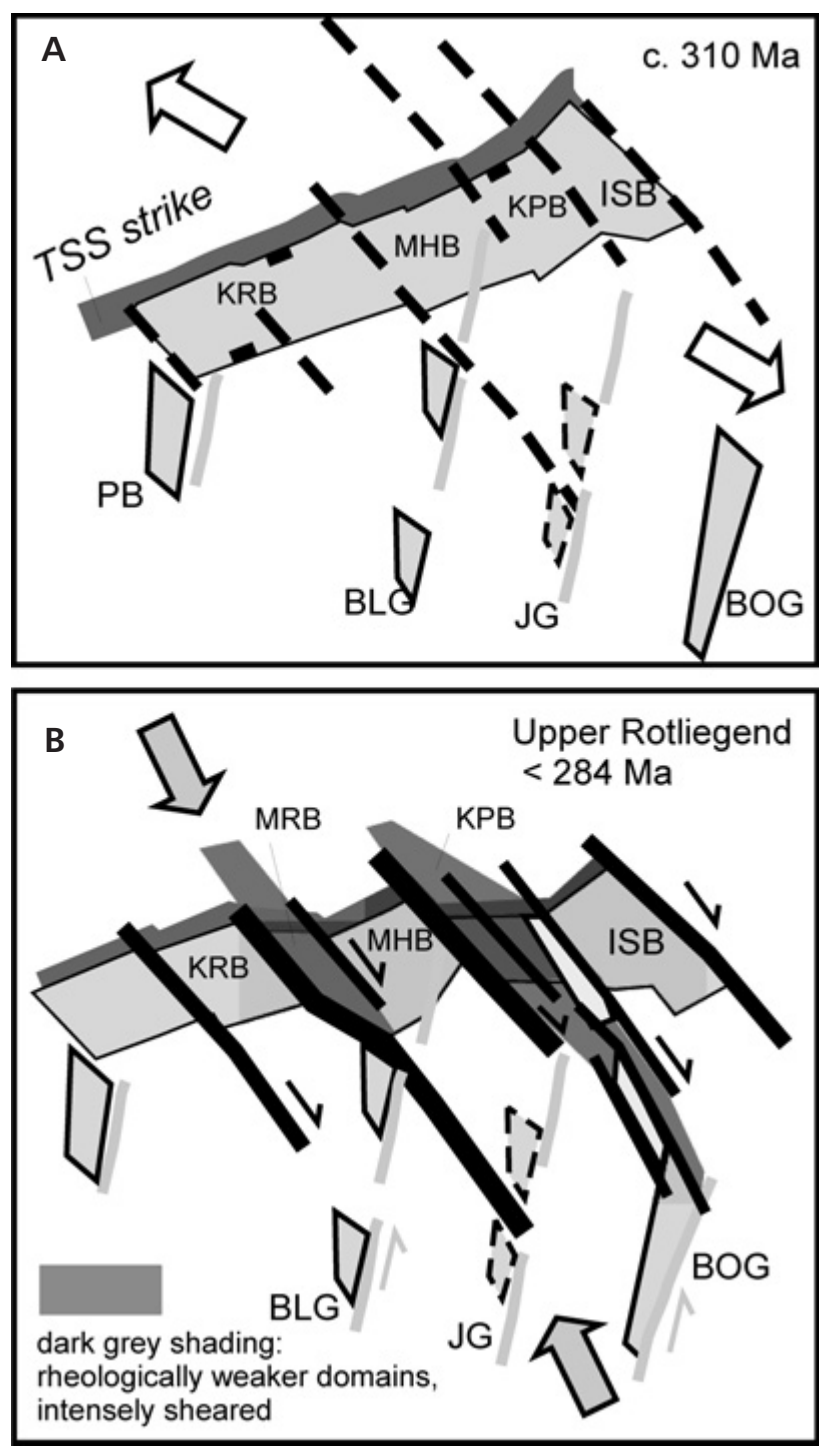

Figure 8. Sketch showing the interpreted role of faults of the Labe and Sudetic FGs in deformation of the belt of Carboniferous extensional basins. For tectonic context see Figs 1 and 4 through 7. A - extensional basins form along the strike of the TSS (Teplá-Barrandian/Saxothuringian suture) during the post-orogenic extensional collapse at $\mathrm{ca} 310 \mathrm{Ma}$. The Labe FG faults probably act as transfer zones separating individual extensional grabens in a dominant WNW- or nearly E-W-oriented extension (cf. Pitra et al. 1999); B - near the end of the Early Permian or later (Upper Rotliegend, Artinskian/Kungurian, < $284 \mathrm{Ma}$ ), dextral shearing dominates along faults of the Labe and Sudetic FGs, with localized pull-apart basin formation ( $c f$. Uličný et al. 2002). In weaker domains along the Labe and Lužice Fault Zones, the shearing causes the nearly E-W trend of the outline of the Krkonoše Piedmont and Mšeno-Roudnice basins. Abbreviations: BLG - Blanice Graben, BOG - Boskovice Graben, ISB - Intra-Sudetic Basin, JG - Jihlava Graben, KPB - Krkonoše Piedmont Basin, KRB - Kladno-Rakovník Basin, MHB - Mnichovo Hradiště Basin, MRB - Mšeno-Roudnice Basin, PB - Plzeň Basin.

dence only in a part of the palaeovalleys, they do not have a role in the genetic correlation framework in the Bohemian Cretaceous. 


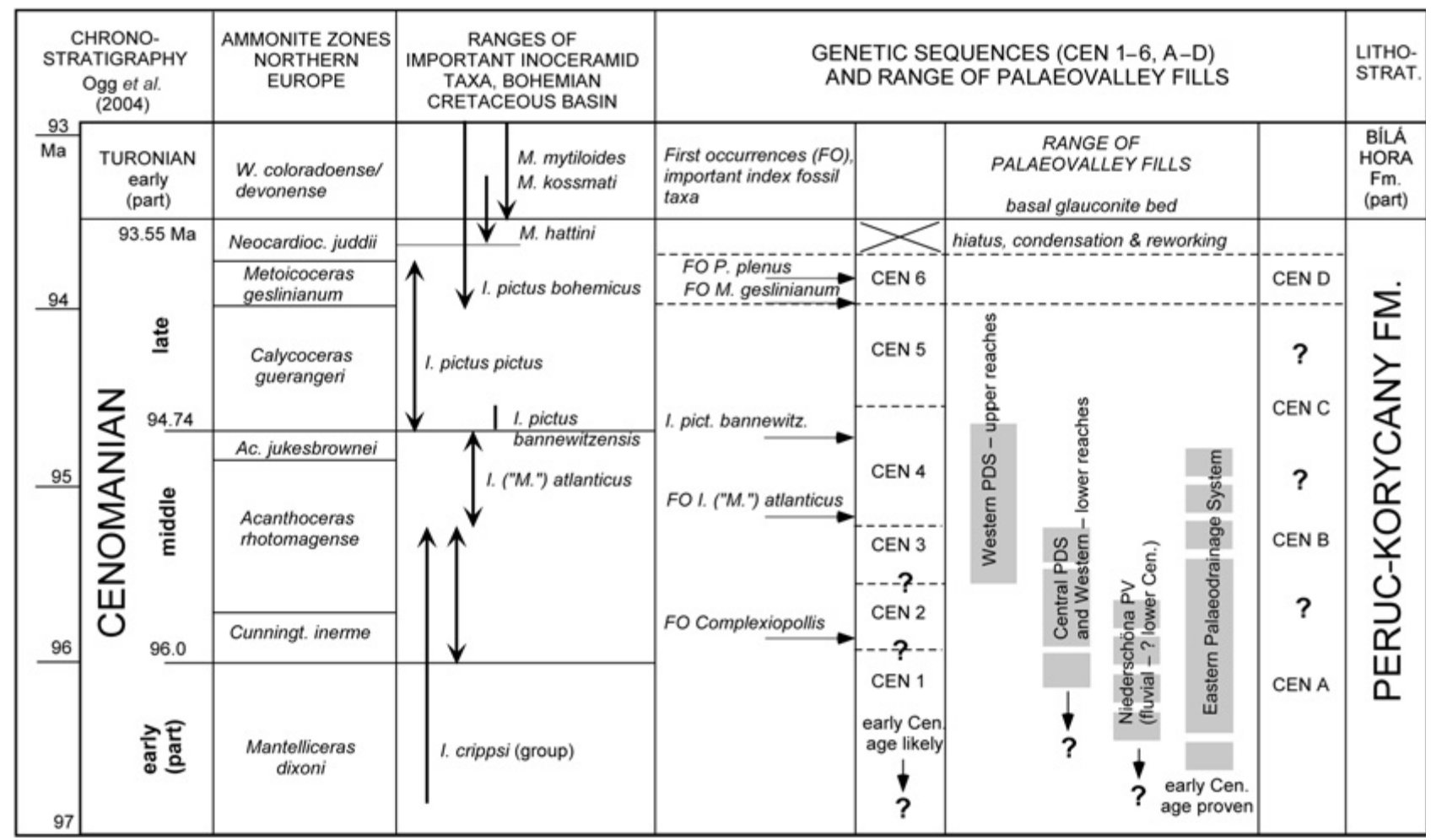

Figure 9. Chart showing the chronostratigraphic position of the infills of individual parts of the Bohemian Cretaceous Basin palaeodrainage. Note the loss of chronostratigraphic resolution downsection, where only palynological data are available. The first occurrence of Complexiopollis pollen from the Normapolles group used to be reported as a marker of a late middle to late Cenomanian age, correlated to the Acanthoceras jukesbrownei Zone (Pacltová 1971, 1977). In the Central Palaeodrainage System it was found near the base of sequence CEN 2 (borehole Jb-1, $363.2 \mathrm{~m}$ depth). This is well below the Acanthoceras jukesbrownei Zone marked by the FO of Inoceramus ("Mytilodes") atlanticus near the base of CEN 4. It is possible that the Normapolles group appeared in the Bohemian region close to the beginning of the middle Cenomanian.

\section{Genetic sequences - overview}

Correlation of genetic sequences in non-marine to marginal-marine strata typically has to rely on a physical connection between correlated sections, unless independent, high-resolution methods of correlation are available. Stratal successions developed partly or entirely in different palaeovalley or sub-basin systems typically pose problems in correlation. As shown in Figs 10A and 13, the Bohemian Cenomanian valley-fill complexes developed in several PDSs termed here the Central, Western, Northern, and Eastern PDS. The genetic stratigraphy originally developed in the Central PDS (Uličný et al. 2003b) can, to a large extent, be applied to the Western and Northern PDSs because they became a single depositional region relatively soon in their evolution. However, an independent genetic stratigraphic scheme had to be established for the Eastern Palaeodrainage that was separated from the other PDSs by a major drainage divide (Fig. 10A). The lack of sedimentological and well-log data from the German part of the basin prevents closer correlation with the Niederschöna Palaeovalley.

Infill of the Central, Western, and Northern PDSs. - Six genetic sequences, labelled CEN 1-CEN 6, are recognized in the central and western parts of the basin, spanning middle to late Cenomanian age, with unproven but possible

Figure 10. Schematic maps of the tectonic and palaeogeographic setting of the Bohemian Cretaceous Basin before the beginning of deposition on the base-Cretaceous unconformity (A) and during the late Cenomanian Metoicoceras geslinianum Zone (B). In (A), corresponding to late early to early middle Cenomanian time, main topographic palaeohighs $(\mathrm{PH})$ and lows with generalized palaeodrainage axes are illustrated, together with proven occurrences of early Cenomanian coastal facies in the NW (Meissen area) and tide-influenced to estuarine facies in the SE (Blansko Graben). Yellow-filled circles and labels indicate locations of sections shown in Fig. 11. In (B) the reconstructed palaeogeography and place names mostly follow Uličný \& Čech (in S. Voigt $e t$ al. 2008, pp. 953-959), as modified from Valečka et al. (2003) and other sources. The Káranice Palaeohigh is defined as a series of ridges originally named "Mlékosrby Palaeohigh" by Klein et al. (1982). Because the Mlékosrby village is, in fact, located above a part of a palaeovalley fill, this name is disused here. In the same way, the "Podlažice depression" of Vajdík \& Vybíral (1973) is referred to as the Skutíčko Palaeovalley here, because of the location of Podlažice above a local palaeohigh. Abbreviations: LuFZ - Lužice Fault Zone, ZHFZ - Železné hory Fault Zone. Further comments in text. 
David Uličný et al. • Palaeodrainage systems at the basal unconformity of the Bohemian Cretaceous Basin

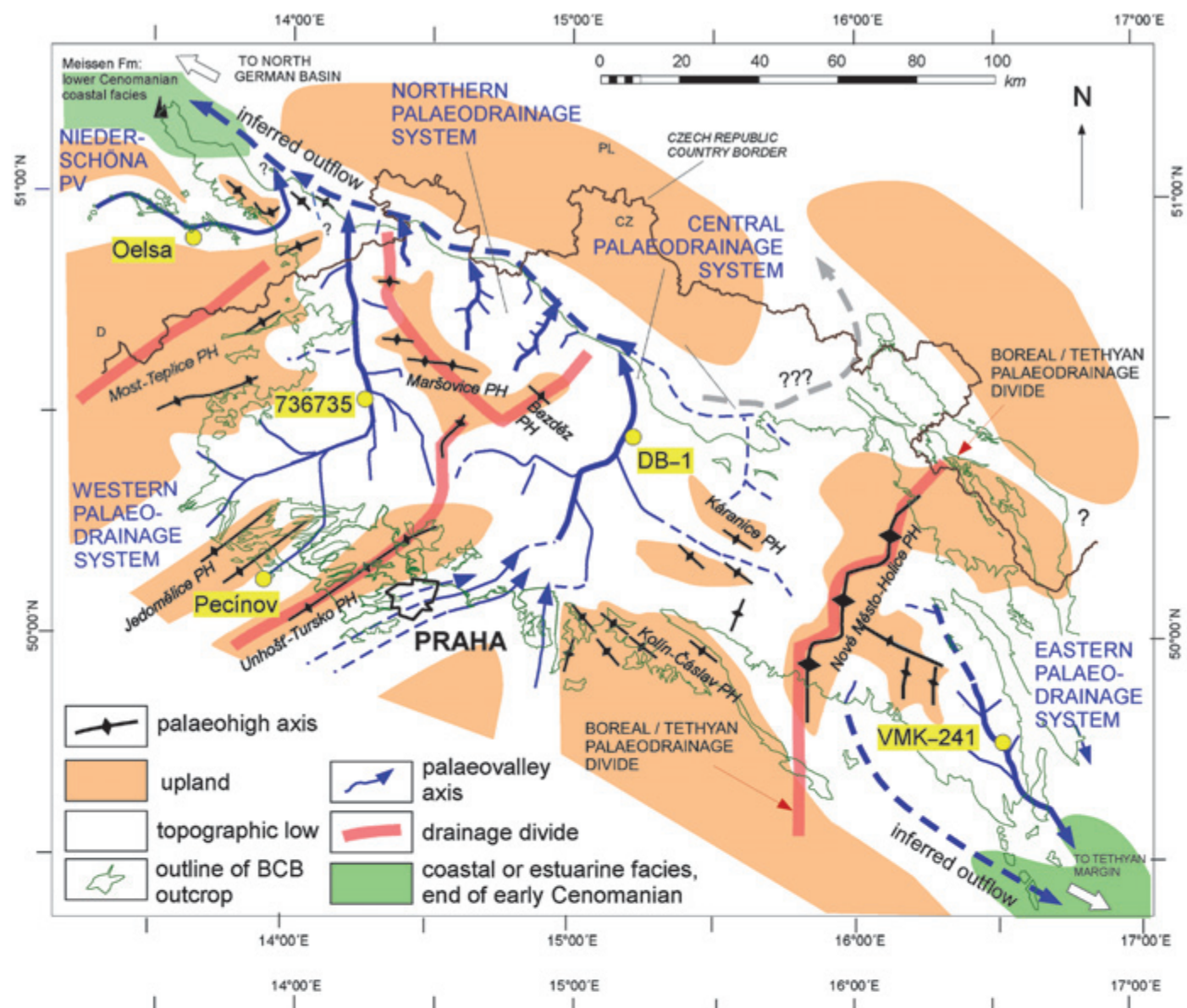

A

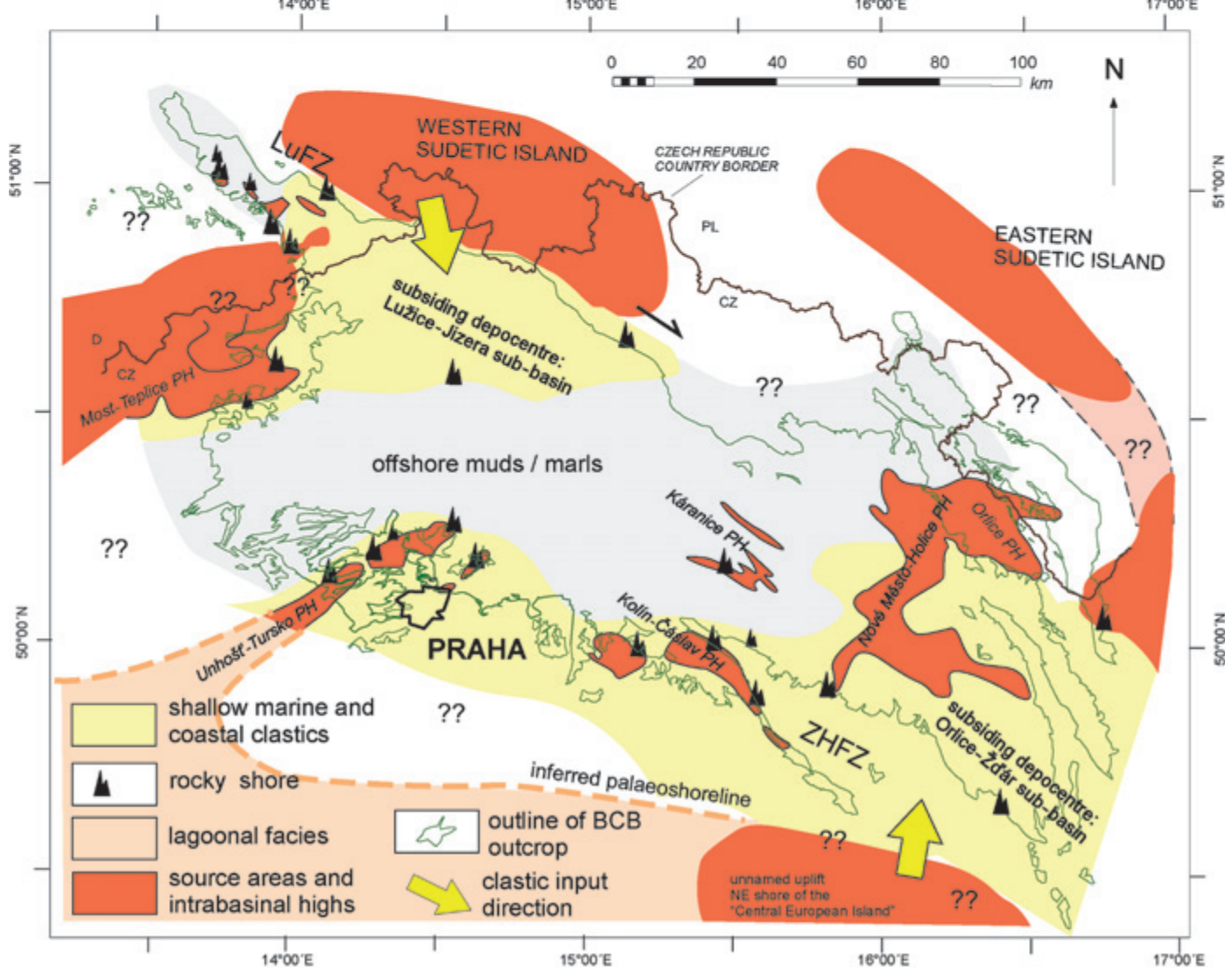


early Cenomanian age in the lowermost unit (Fig. 11). Smaller scale sequences of a yet higher frequency can be detected within these major sequences, but irregular data coverage mostly prevents correlation on an appropriate level of detail.

Sequences CEN 1 and CEN 2 are defined as predominantly fluvial, valley-filling strata, in the Central, Western, and Northern PDSs. Only in the Central Trunk Valley and its tributaries the base of CEN 2 can be correlated with confidence. In the Western PDS, the two sequences are correlated as one unit CEN $1+2$ (see Appendix 1 for details). Unit CEN 3 is marked by a significant paralic flooding of much of the basin, with tide-dominated estuaries established in both the Western and Central PDSs that began to merge into a single depositional area during this time. Because of the prominence of the CEN 3 flooding, the level of onlap of this unit on the basement, as determined by interpolation between correlated boreholes, was chosen as a marker to define the limits of fluvial palaeovalley fills of CEN 1 and 2 sequences. Only in the most updip part of the Western PDS, fluvial strata correlative to CEN 3 are preserved (Figs 11, 14A) and their extent is used to map the headward continuation of the palaeovalleys. Because of the focus in this paper on the initial palaeodrainage network, downdip estuarine and coastal palaeogeography of CEN 3 and younger sequences are not shown.

Between the time of sequence CEN 4 and the major flooding event at the base of the Bílá Hora Fm. (Turonian), shallow-marine conditions gradually spread over most of the western part of the basin. The basal surfaces of CEN 5 and CEN 6 mark significant steps in basin floor drowning, attributed to increased subsidence rates by Uličný \& Čech in S. Voigt et al. (2008). Only a few palaeohighs remained emerged during the CEN 6 time, such as the Most-Teplice Palaeohigh (with locally developed paralic facies in the vicinity; Fig. 10B, Čech \& Váně 1989) and the axial part of the Holice-Nové Město Palaeohigh (Fig. 10B).

Infill of the Eastern PDS. - Four distinct genetic sequences were defined in the Eastern PDS, labelled CEN A through CEN D, following Kanta (2000), with some modifications. CEN A-CEN C represent a series of steps in filling of a large palaeodrainage. The earliest unit is sequence CEN A, dominated by sand and gravel-rich, braided rivers, followed by finer-grained fluvial deposition of CEN B and estuarine and shallow-marine deposits of CEN C and D, respectively. A relict of an axial part of a palaeovalley fill in the Blansko Graben shows probably an equivalent of the lowermost CEN A, with palynoflora indicative of lower Cenomanian age (Svobodová 1992, 1997, Svobodová \& Brenner 1999). Due to problems in correlating the Blansko Graben succession to the sequences defined in the rest of the Eastern PDS, it is not known exactly to which level (CEN B or ?C) belong the occur- rences of dwarf faunal forms in the Blansko Graben (Zvejška 1953, B. Zahálka 1950), interpreted as indicative of restricted marine/brackish conditions (Čech in Uličný et al. 2004).

Sequence CEN D correlates to CEN 6 west of the Nové Město-Holice Palaeohigh. In the same way as CEN 6 in the West-central part of the basin, CEN D marks major changes in basin infill style in the late Cenomanian. It is a package of shallow-marine sandstones that prograded from the south into a new depocentre at the southeastern edge of the basin (Fig. 10B; $c f$. Frejková \& Vajdík 1974), and the wedge-shaped cross-sectional geometry shows a clear increase in subsidence to the SSW during this time (Fig. 14B). Importantly, this onset of subsidence along the Železné hory and, possibly, the Sázava FZ was accompanied by localized uplift and erosion of parts of the older basin fill (Frejková \& Vajdík 1974, Hypr et al. 1982, Kanta 2000, Uličný et al. 2004).

\section{Palaeodrainage systems of the Bohemian Cretaceous Basin - overview of key features}

As shown in Fig. 10, an important feature of the Cenomanian palaeotopography in the study region was the Nové Město-Holice Palaeohigh, trending roughly NNE, which played the role of a relict European drainage divide. Towards the North, it probably continued into the region of the Intra-Sudetic Basin as the interpreted Orlice Palaeohigh (Radwański 1975, his Fig. 3).

Its axis follows the trend of a belt of granitoids interpreted as the northern part of the Nasavrky Massif, and is aligned with Jizera Group faults. The Nové Město-Holice Palaeohigh separated the Eastern PDS, drained to the southeast toward the Tethyan margin, from the rest of the basin until its final submergence during late Cenomanian to early Turonian times (Figs 10, 13). All the PDSs to the west of this divide drained toward the Lužice FZ, with an outflow toward the Boreal palaeogeographic province. The division into the Central, Western, Northern, and Niederschöna PDSs is based on (1) occurrence of sub-regional divides between them, (2) sets of characteristics typical of individual drainage infills, and (3) relationships to basement structures.

\section{Central PDS}

Most of the area of this palaeodrainage is located between the Lužice and Labe FZ, as a broad depression (up to $30 \mathrm{~km}$ in width) filled by fluvial clastics of CEN 1-CEN 2 sequences. The existence of this PDS has been known since the drilling campaigns in the 1960s but its exact geometry was not certain. Prevailing southeastward drainage 
David Uličný et al. • Palaeodrainage systems at the basal unconformity of the Bohemian Cretaceous Basin
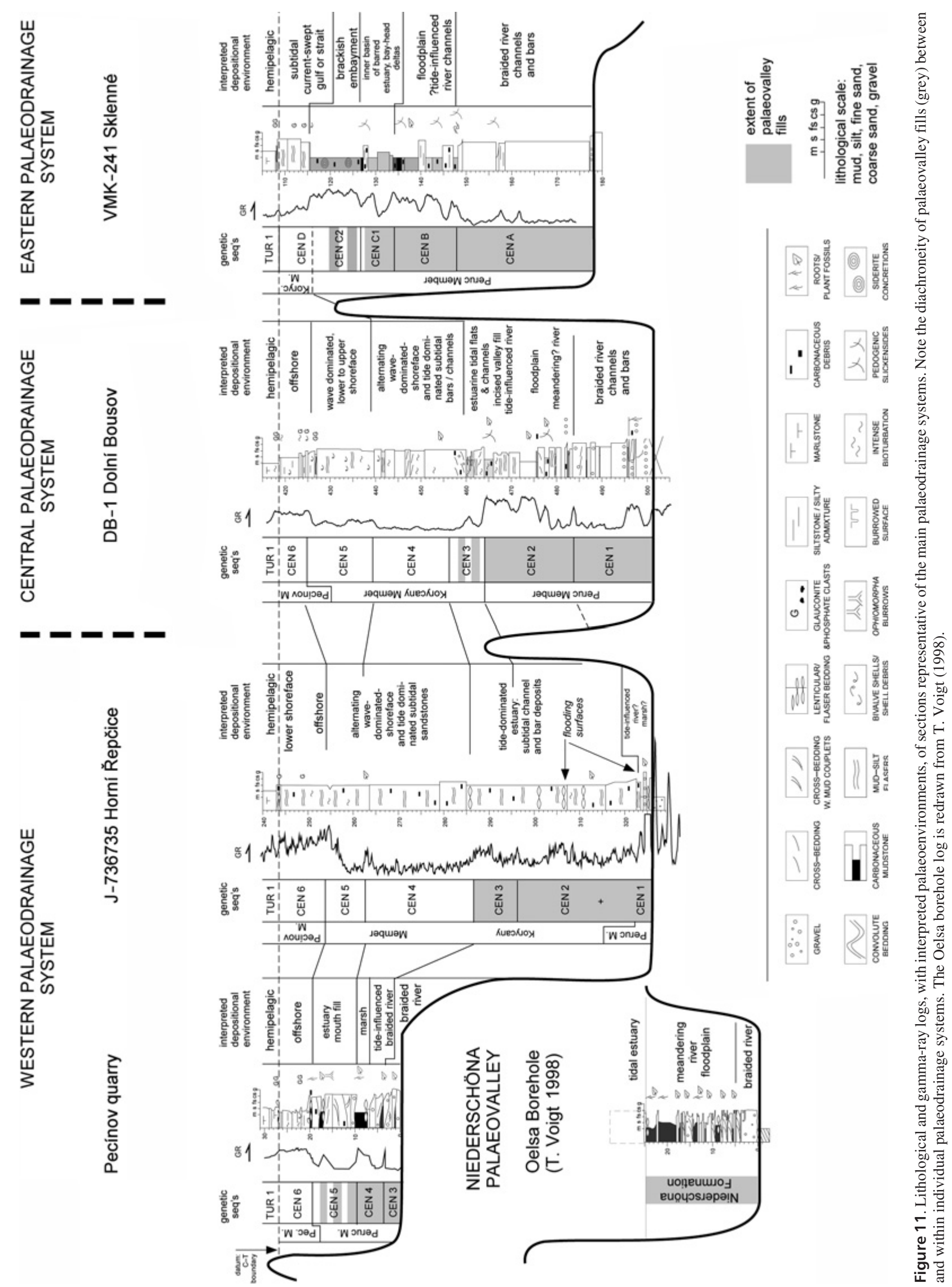


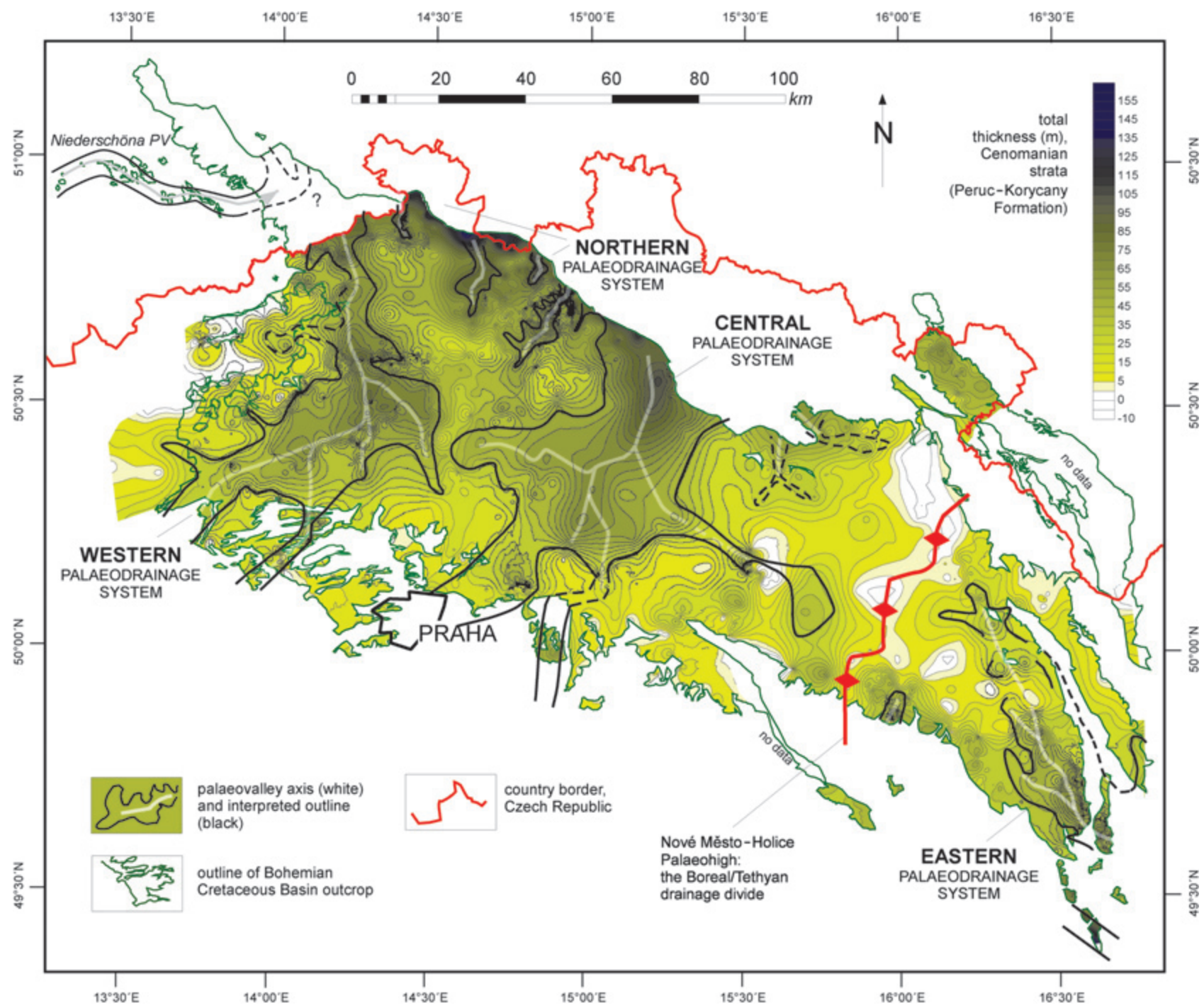

Figure 12. Isopachs of Cenomanian strata in the Czech part of the Bohemian Cretaceous Basin. The map is based on 2,630 data points representing full preserved thickness of the Peruc-Korycany Formation, with the exception of the Brník area, where the Cenomanian is not preserved completely, but in order to indicate the palaeovalley (PV) fills the preserved CEN $1+2$ equivalents are shown.

was inferred by Klein et al. (1979), without supporting evidence, and appears also in T. Voigt (1996).

Main morphological features and relationships to basement. - The Central PDS (Figs 13, 15A) is characterized by a broad central to northern part that collected several narrower tributaries from the South, East and West. The general direction of drainage was to the North, as explained further below. The preserved infill of the palaeodrainage is cut off at its northern edge by the Lužice FZ.

The extent of much of the Central PDS coincides with the extent of the Late Palaeozoic Mnichovo Hradiště Basin below (Fig. 15A). To the East and South, the basal Cenomanian strata overlie Teplá-Barrandian Zone clastics and low-grade metamorphics. Locally, Variscan granites form the subcrop (e.g., along the Luštěnice Fault, Figs 4, 6).
The roughly N-S alignment of isopach maxima marks the axis of the Central Trunk Palaeovalley. It coincides with the Jizera Group faults, detected in the Mnichovo Hradiště Basin area, and shows an apparent right-lateral offset approximately in the centre of the palaeodrainage. The same strike is followed by one of the tributaries in the southern part of the PDS, the Brník Palaeovalley, aligned nearly $\mathrm{N}-\mathrm{S}$ along the Kourrim Fault.

Another tributary, the Nehvizdy-Vykán̆ Palaeovalley, is aligned with the typical ENE structural trend of the Teplá-Barrandian Zone. This palaeovalley splits into at least two lower-order streams (Špičáková 1999; Figs 13, 14A, 15A). Near the southwestern limit of its preserved extent, on the eastern edge of Prague, the Nehvizdy-Vykán̆ Palaeovalley probably represented a broad, low-lying trough partitioned into a number of parallel valleys due to 


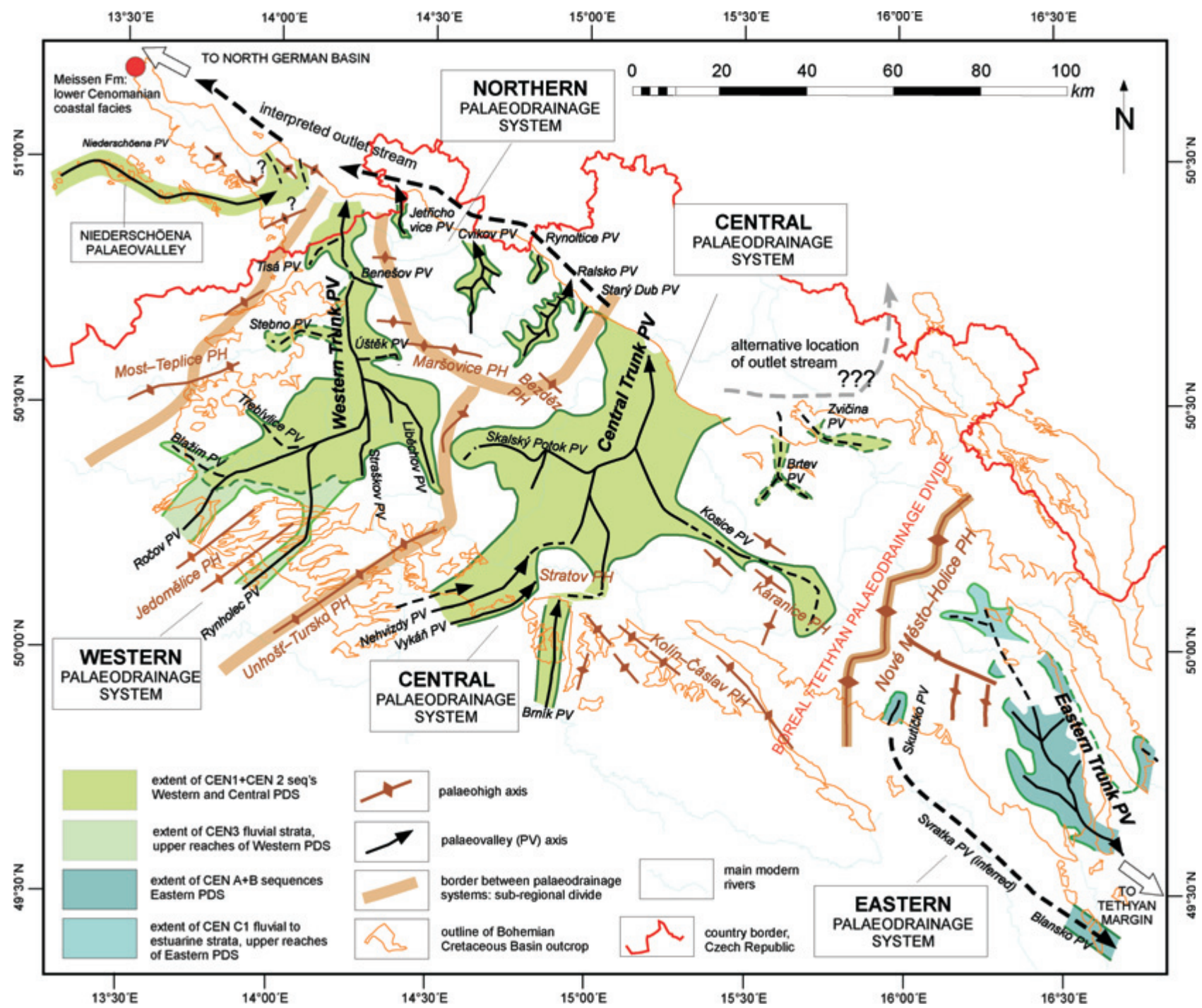

Figure 13. Interpretative map showing the extent of fluvial to estuarine infills of individual palaeodrainage systems as defined in this study. See text for comments on criteria for the map construction.

contrasts in erosional resistance of Ordovician clastics (shales vs. orthoquartzites; $c f$. Matějka 1921). Erosional relicts and palaeokarst infills in the southwestern part of Praha and further southwest (Kodym 1923, Zelenka 1987, Bosák 1995) suggest a headward continuation of this palaeovalley along the same strike of the Teplá-Barrandian Zone structural grain. The maximum preserved length of the Central PDS, measured along the Brník tributary valley, is $c a 80 \mathrm{~km}$.

From the West and East, the Central PDS was entered, respectively, by the Skalský potok and Kosice palaeovalleys (Figs 10, 13), both trending W-NW and aligned with the Labe Group faults. The easternmost position of the head of the Kosice Palaeovalley is not certain but the connection interpreted in Figs 11 and 13 is supported by correlation of lithofacies and well-log patterns across an area of poor borehole coverage in the Nový Bydžov region.
Two small relicts of palaeovalley fills are found to the East along the northern edge of the Central PDS, with a maximum preserved length of $18 \mathrm{~km}$ and widths between 1 and $2 \mathrm{~km}$. They are arbitrarily joined here with the Central PDS. The Brtev Palaeovalley runs generally north, suggesting an alignment with Jizera Group faults or fractures, but another minor palaeovalley further NE shows a clear alignment with the Zvičina Fault (Fig. 13).

Fluvial to estuarine infill. - The fluvial infill of the Central PDS is represented by sequences CEN 1 and CEN 2. It is up to $50 \mathrm{~m}$ thick and $35 \mathrm{~km}$ wide and shows a moderate southward decrease in thickness, with the exception of the Brník Palaeovalley where preserved fluvial strata are almost $48 \mathrm{~m}$ thick (Fig. 14A) and the part correlated to CEN 2 is twice the thickness compared to localities further North (downstream), across the Labe FZ. 

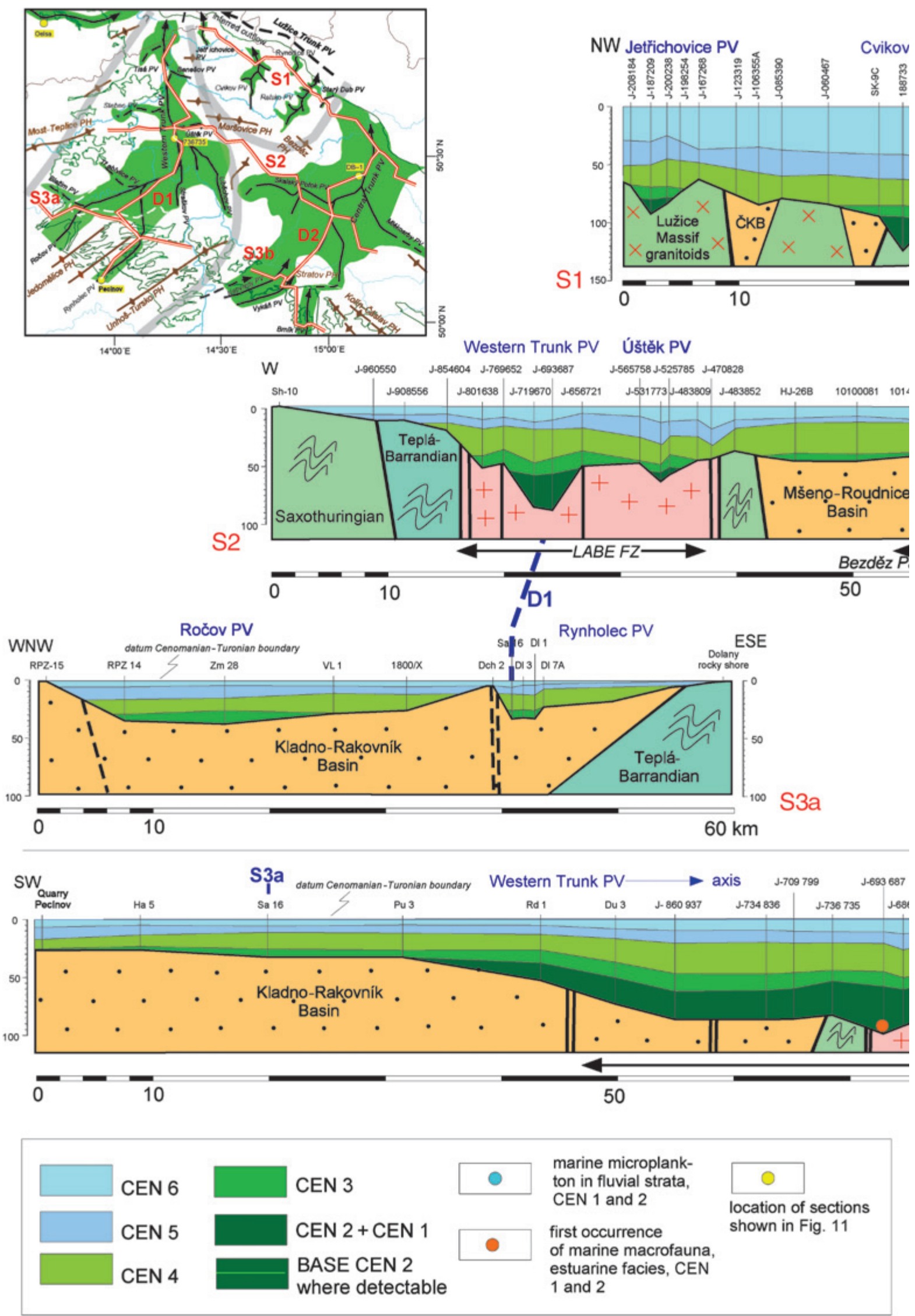

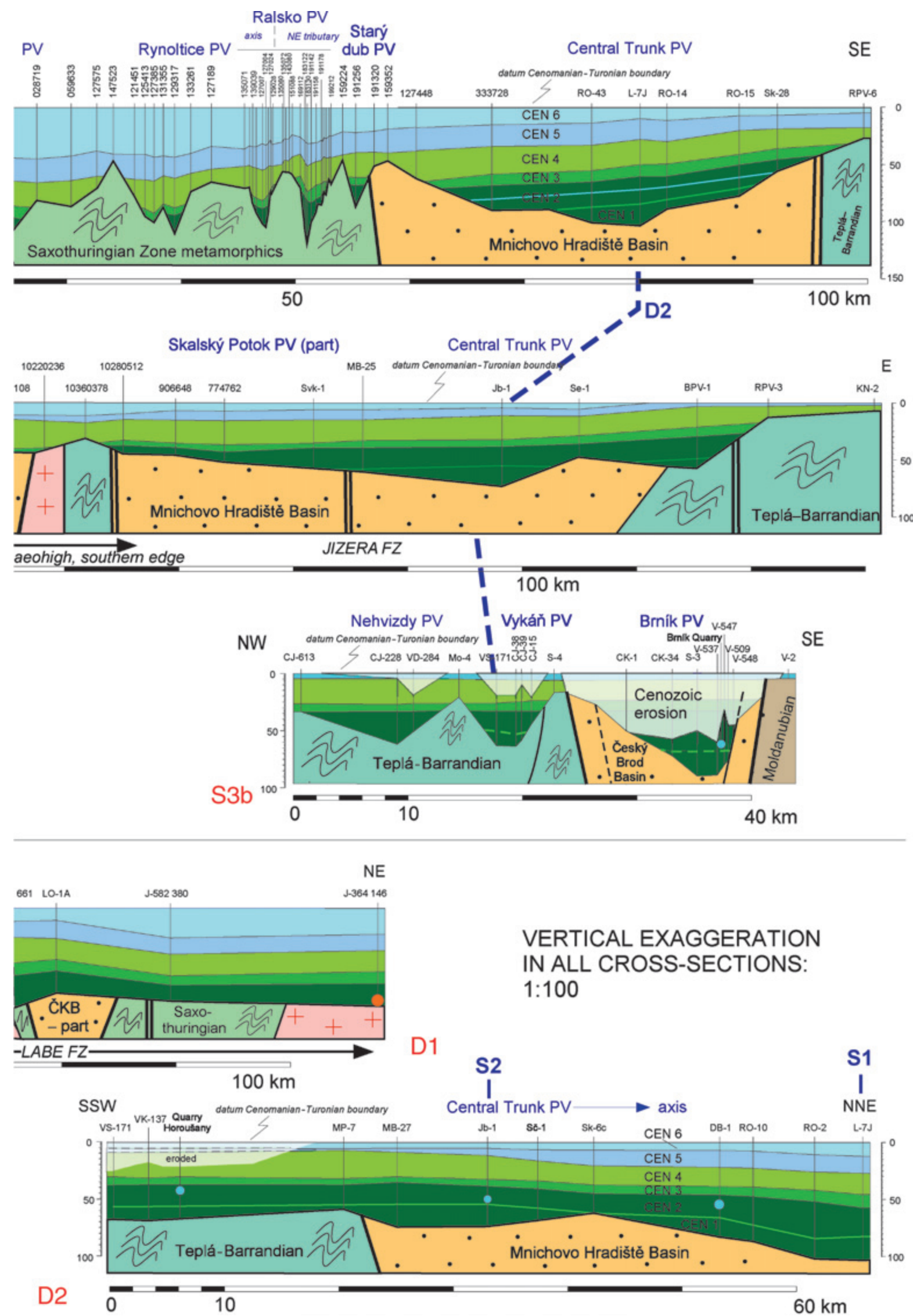


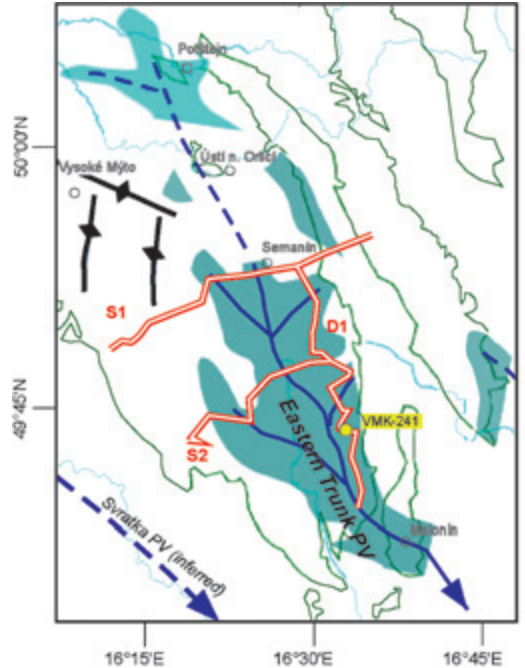

\section{VERTICAL EXAGGERATION IN ALL CROSS-SECTIONS: $1: 100$}

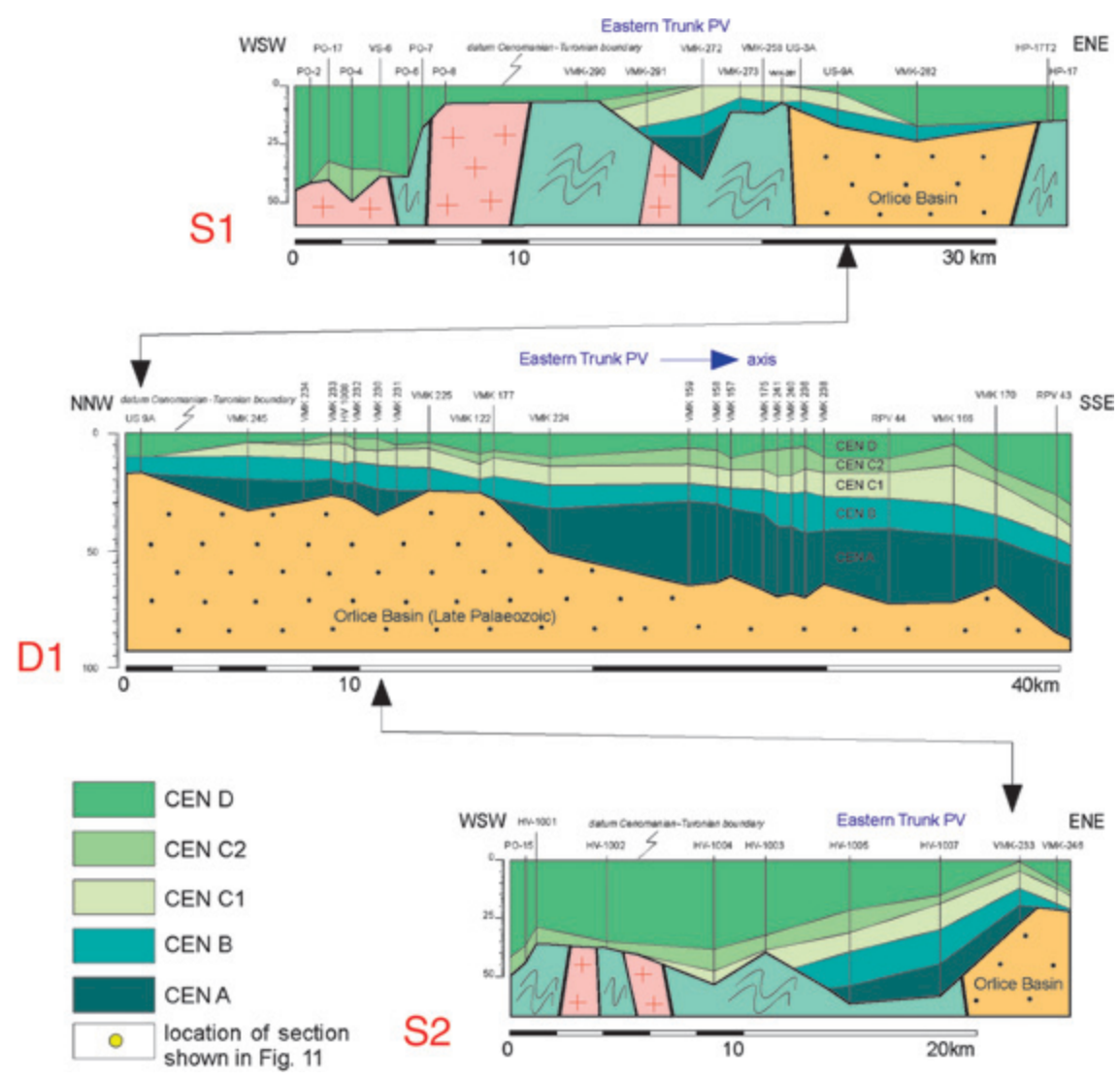

Figure 14. Correlation panels hung on the base of the Turonian, as correlation datum, showing the distribution of palaeodrainage fills (green in inset map) and other parts of the Cenomanian depositional record, along lines shown in insets, for the Western, Northern, and Central (A) and Eastern (B) palaeodrainage systems. Correlation lines following the structural strike of the basin are labelled S1 through S3, whereas dip-parallel lines are labelled D1, D2. Detailed correlation panels showing distribution of lithofacies in cross-sections D1 and D2 are presented in Appendix 1. ČKB - Česká Kamenice Basin. Comments in text.

Cross-strata in outcrops in the Nehvizdy-Vykán̆ and Brník Palaeovalleys indicate palaeoflow to the NE and N (Špičáková 1999). Between the Labe FZ the Cenomanian does not crop out, but the palaeoflow towards the Lužice FZ is clearly indicated by sedimentological and palynological evidence: (1) Tidal influence on deposition of the fluvial strata of CEN 2 is indicated by the sporadic presence of acritarchs and dinocysts near the base of the unit that increases toward the top of this unit, with the first indices of brackish to marine water influx climbing stratigraphically up to the South (boreholes RO-43, DB-1, Jb-1, Nehvizdy Quarry; Figs 11, 14A, and Appendix 1). Subunit CEN 2c, represented by well-correlatable infills of tide-influenced fluvial channels, passes into intertidal flat and channel-fill heteroliths toward the centre of the trunk palaeovalley and to bioturbated, estuarine channel fills in the North; (2) General thinning of fluvial strata to the South (Appendix 1) is accompanied by apparent pinchout of the oldest known part of CEN 1 in the same direction; (3) Sequence CEN 3, interpreted as estuarine strata (Špičáková 1999, Uličný et al. 2004), comprises fine-grained and heterolithic, marsh and tidal-flat facies in the southern and central parts and increasingly sandy, subtidal facies northward.

Heavy mineral data from cores in the Central Trunk Palaeovalley provide additional support for drainage toward the Lužice FZ: staurolite and kyanite were found in fluvial-estuarine strata in many boreholes in the central and northern parts of the Central PDS, including DB-1 and Sč-1 boreholes (Fig. 14 and Appendix 1; cf. Vejlupek et al. 1967, Holub et al. 1972, Pražák et al. 1984, Tásler et al. 1986). These minerals indicate provenance from highgrade metamorphics of the Kutná Hora Metamorphic Complex of the Moldanubian Zone (Slavík 1984; $c f$. Klein et al. 1957) and bring further support to the northward drainage. Provenance from the North is unlikely as at present low-grade metamorphics of the Saxothuringian Zone are exposed in that region, and during the Cenomanian, the exposed rocks must have been even lower-grade than at present, or possibly Late Palaeozoic sediments (Uličný et al. 2004, and Konopásek, pers. comm. 2004).

Controls on palaeotopography. - The alignment of interpreted valley axes clearly shows that above Late Palaeo- 
zoic basin fills, orientation of the palaeodrainage was governed by the dominant conjugate system of the Jizera and Labe FG, with the Jizera Group faults playing a more significant morphological role. Thickness distribution of fluvial to estuarine units does not indicate syndepositional displacement along the basement faults, except in the Brník Palaeovalley.

The explanation of the localized increase in thickness is that a reactivation of the Kourim Fault during the time of CEN 2 led to localized subsidence in the palaeovalley roughly coinciding with the extent of the underlying Český Brod Basin, probably a Permian-age pull-apart structure (Fig. 8). Contemporaneous local uplift of the Kutná Hora Metamorphic Complex to the East of the Kourim Fault is suggested by heavy mineral assemblages in the arkosic sandstones of the upper part of CEN 2 in the Brník Palaeovalley ( $c f$. Passer 1967, Klein 1957, Špičáková 1999). The fact that north of the Labe FZ there is no detectable syndepositional subsidence along the same Jizera FG structures can be explained in two ways. Either discrete fault movement did not occur north of the Labe FZ due to a difference between local palaeostress fields, or a subtle deformation in that region is difficult to detect with the borehole spacing available.

The lack of borehole data within the Labe FZ also complicates the interpretation of the dextral offsets of palaeovalley trends within the Central PDS. The trend of the Brník Palaeovalley is offset at its northern end, within the Labe FZ. The Central Trunk Palaeovalley shows a dextral offset probably along the marginal fault of the Sukorady sub-basin of the underlying Mnichovo Hradiště Basin (Figs 4, 6, 13). In addition, the downstream continuation of the axis of the Nehvizdy-Vykáň Palaeovalley seems to have been abruptly obstructed or offset by the Stratov Palaeohigh that is transgressed by the uppermost marine Cenomanian strata at the junction with the Labe FZ (Figs 10A, 13). In this area of poor borehole coverage, a suitable explanation could be one of the following: (i) post-depositional displacement, in agreement with the interpretation by Uličný et al. (2009) of Turonian activity of the Labe and Jizera FG, and/or (ii) at least partly syndepositional displacement, or (iii) river courses simply following traces of old, inactive fault zones. The presumed activity of the Kouřim Fault brings indirect support to the possibility of syn-or post-depositional displacement (compare also with the Eastern PDS documented below). Correlations in Uličný et al. (2004) suggest minor uplift of a ridge parallel to the edge of the Kosice Palaeovalley probably during deposition of CEN 3 sequence.

The widths of the individual parts of the Central PDS change depending on the resistance of the substrate to erosion. The broadest part, the Central Trunk Palaeovalley, was developed on the Late Palaeozoic basin fill. Among the tributary valleys aligned with the Labe Group faults, the Kosice Palaeovalley that developed on the pre-Carboniferous, Teplá-Barrandian Zone substratum is markedly narrower than the Skalský potok Palaeovalley overlying Late Palaeozoic clastics.

\section{Western Palaeodrainage System}

The Western PDS is located partly within, and mostly to the west of the Labe FZ (Fig. 13). Parts of a prominent drainage system in the western part of the basin have been described by several authors in the past (Soukup 1954; Vachtl 1962; Jelen \& Malecha 1987; Valečka 1974, 1979), but the early palaeogeographic interpretations showed isolated areas of "freshwater deposits" without mutual connections or with a hypothetical drainage toward the southeast, into the basin interior (Fig. 2). Based on new data and the genetic sequence-stratigraphic analysis, a new picture of an extensive system of palaeovalleys drained toward the Lužice FZ is presented here.

Main morphological features and relationships to basement. - The Western PDS comprises two distinct parts, as follows: (1) a broad, generally W-SW-striking belt between the western erosional edge of the Cretaceous basin fill and the western edge of the Labe FZ (near Roudnice nad Labem), and (2) a relatively narrow, north-striking belt within the Labe FZ, from the confluence of the modern Vltava and Labe rivers to the modern Labe River canyon in Hřensko (Fig. 13). There, the axis of the drainage system enters the Saxonian part of the basin and possibly joins the Niederschöna Palaeovalley (see below).

To the west of the Labe FZ, the main elevated areas that bordered the drainage system strike generally ENE: the Most-Teplice Palaeohigh in the North and the Unhošt-Tursko Palaeohigh in the South, with subordinate highs such as the Jedomerlice Palaeohigh in between (Fig. 13; Matějka 1936, Jelen \& Malecha 1988, Čech \& Váně 1989). To the East of the Labe FZ, several minor palaeohighs formed the northern part and continuation of the Maršovice Palaeohigh.

In the western part of the PDS, developed almost completely on Upper Carboniferous clastics, the general strike of two prominent drainage axes follows the W-SW strike of grabens of the Upper Palaeozoic Kladno-Rakovník Basin (Fig. 15B). Towards the Labe FZ, the drainage axes show an increasingly prominent N-S alignment which becomes particularly marked in the central part of the Labe FZ. While the Ročov Palaeovalley (Špičáková 1999) runs generally parallel to the marginal faults of the Carboniferous grabens, to ENE up to the centre of the Labe FZ, the more south-lying Rynholec Palaeovalley takes a sharp bend near Slaný to a N-S direction. Further east, three minor but morphologically well-defined, N-S aligned, narrow 


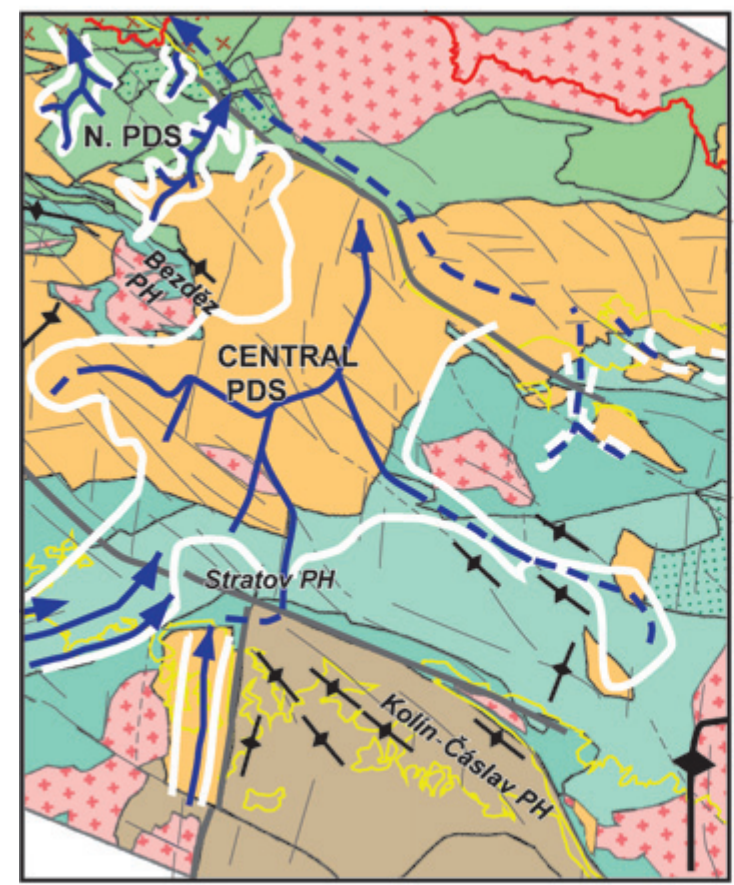

$\begin{array}{llll}0 & 10 & 20 & 30 \\ k m\end{array}$

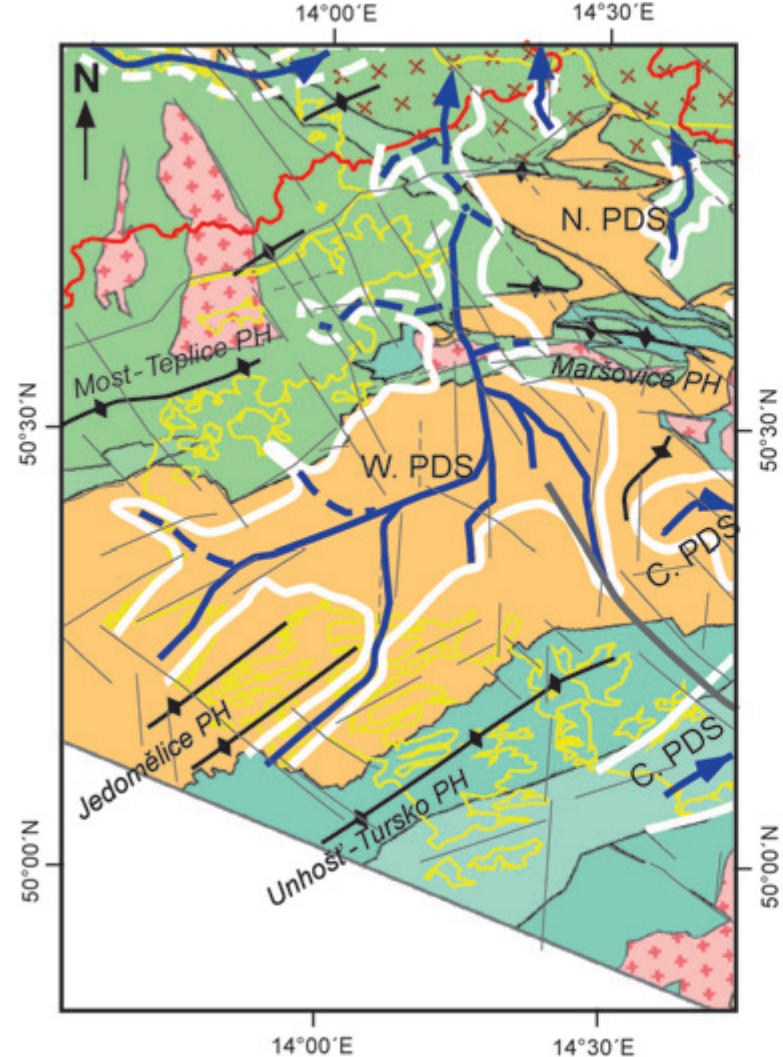

$\begin{array}{llll}0 & 10 & 20 & 30 \\ \mathrm{~km}\end{array}$

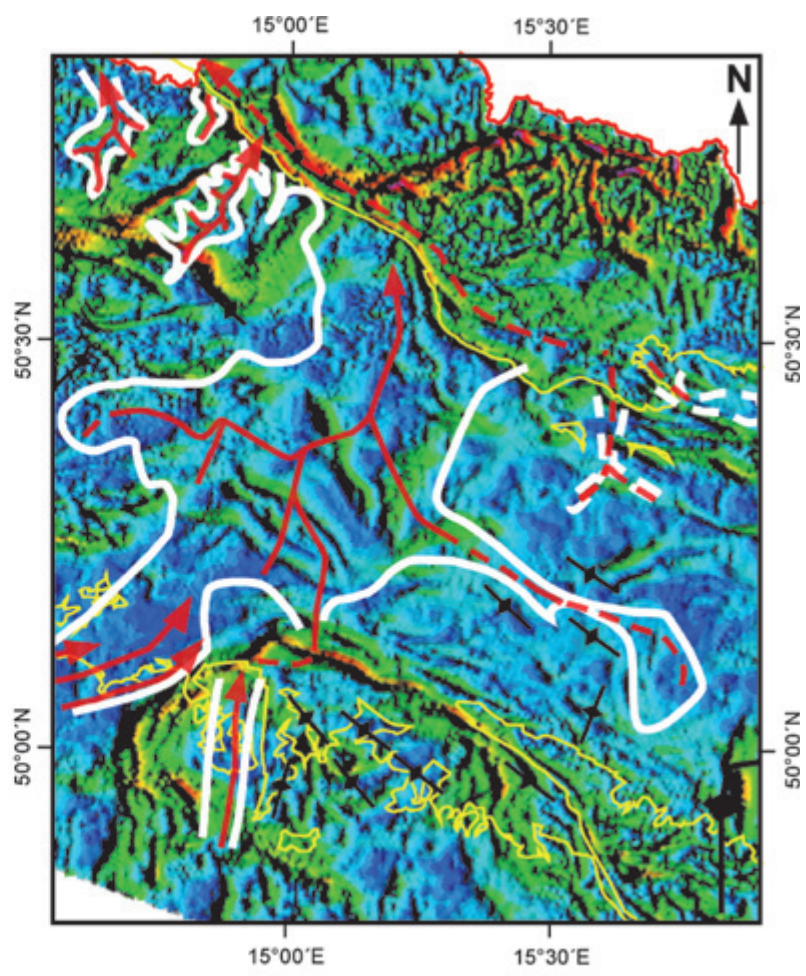

$\begin{array}{llll}0 & 10 & 20 & 30 \\ 0 & & k m\end{array}$

A

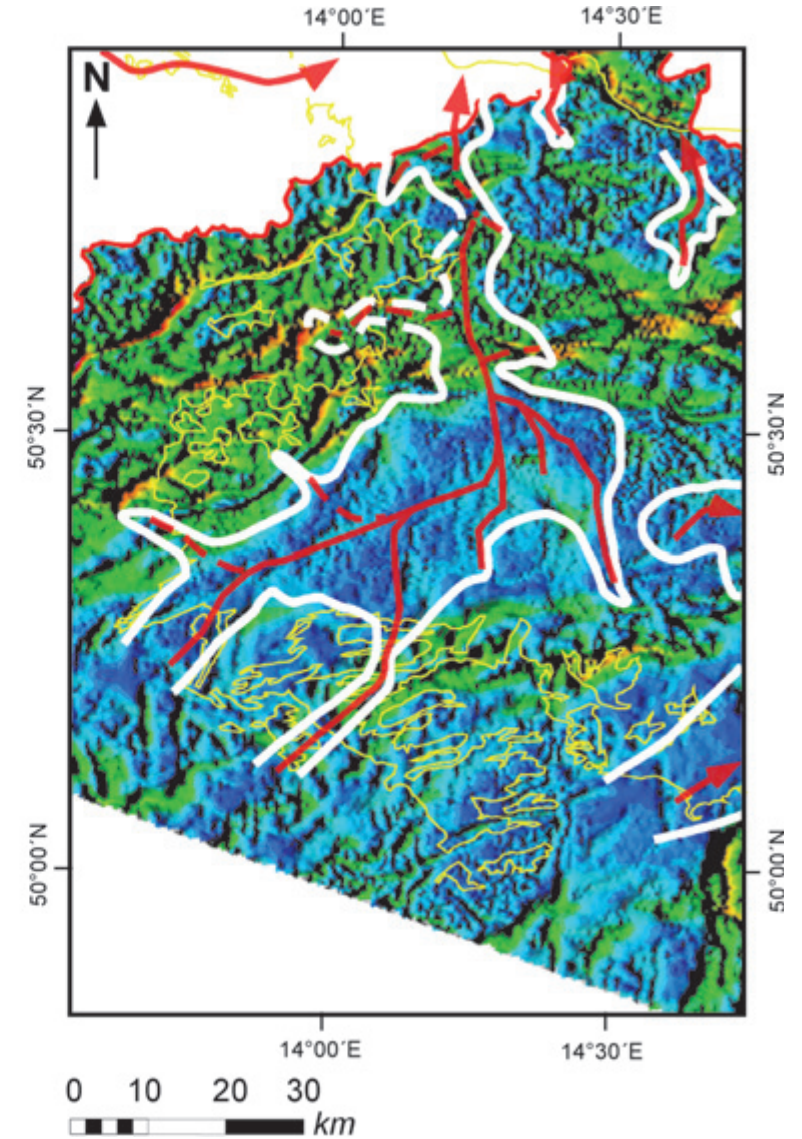

B 

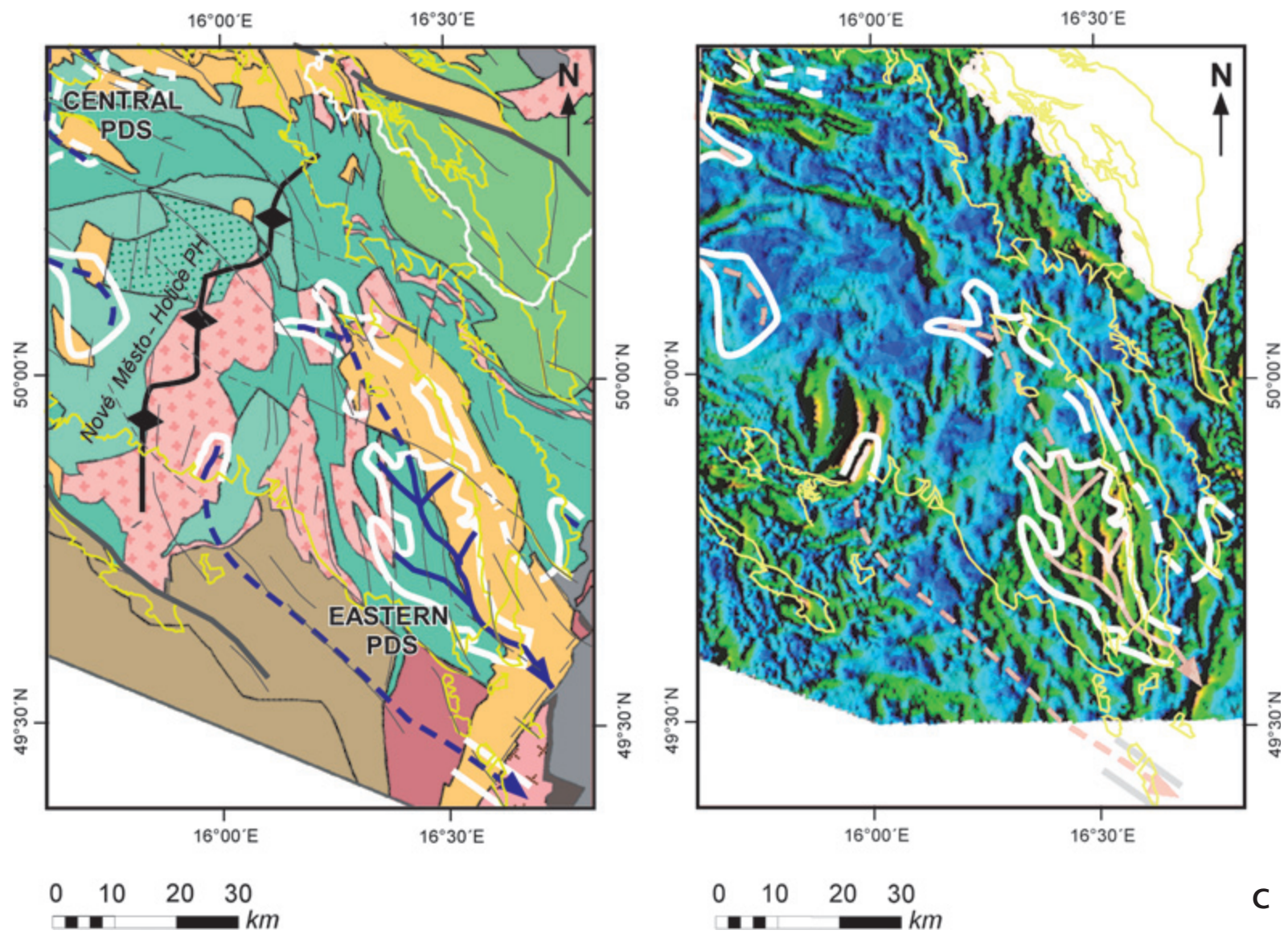

Figure 15. Overlays of the Central (A), Western (B), and Eastern (C) palaeodrainage outlines over details of Cretaceous subcrop map (left) and horizontal gravity gradients (right), showing the relationships of the PDS elements to the basement units and fault zones. Comments in text.

tributaries existed that merged northward to form the Western Trunk Palaeovalley. This palaeovalley is locally constricted to less than $4 \mathrm{~km}$ width between Litoměřice and Úštěk and runs generally to the North (Figs 13, 15B). Details of the morphology of the part of the Western PDS between the Úštěk area and the Czech state border are impossible to evaluate because of a less dense borehole coverage than elsewhere (Fig. 11) and problems caused by Cenozoic faulting and volcanics disrupting the Cretaceous strata in the Ohře Graben area. In the Děčín area, new data permitted an interpretation of an apparently isolated palaeovalley fill, described by Valečka (1979), as a western tributary to the Western Trunk Palaeovalley.

Fluvial to estuarine infill. - The lower part of the infill of the Western PDS correlates with CEN 1-CEN 2 sequences in the Central PDS. Only in the lowermost few metres of the infill of the Western PDS trunk valley, strata without signs of marine influence are found locally (well J-693687, panel D1 in Appendix 1; Fig. 14A). Otherwise, sandstone-dominated facies with abundant bioturbation (Palaeophycus, Thalassinoides) and bivalve shells overlie the base of the palaeovalley in the northernmost boreholes on the
Czech territory. This indicates that estuarine conditions existed in the northern part of the valley while in the southern, upstream part of the palaeodrainage, fluvial facies were deposited in the tributary valleys (Liběchov and Úštěk Palaeovalleys). This unit laps out in the Peruc area (Figs 14A, $15 \mathrm{~B})$. It is overstepped further headward by sequence CEN 3 that in the most upstream tributary valleys was represented by fluvial strata (Appendix 1), while the downstream part of the palaeodrainage has become a major estuarine embayment connected to the flooded Central PDS. In the Rynholec Palaeovalley, tide-influenced fluvial strata, showing northeastward palaeoflow, and supratidal marsh deposits (Uličný \& Špičáková 1996) are interpreted as the most upstream preserved equivalents of sequence CEN 4 (Fig. 11).

Controls on palaeotopography. - Basement fracturing by all three main regional FGs (Labe, Jizera, Ohře) influenced the locations and extent of segments of the Western PDS. The ENE structural trend of the Ohře FG is prominent only in the western part of this palaeodrainage, i.e., beyond the highly faulted area of the Labe FZ. Even within the Kladno-Rakovník Basin area, however, numerous N-S basement structures of the Jizera FG, shown as a subtle, but 
pervasive pattern in the horizontal gravity gradients (Figs 7, 15B), affected the palaeodrainage trend. The N-S strike is prominent in the detailed location and alignment of valley axes within the Labe FZ, where N-S aligned tributaries were located parallel to present-day N-S reaches of the Labe and Ohře rivers and to the Liběchovka FZ. In general, the influence of the Jizera FG on the mid-Cretaceous palaeotopography was much stronger than previously thought. In spite of the fact that the Labe FZ itself is defined by parallel NW-striking faults (synthetic Riedel shears of the Elbe Zone sensu lato), the antithetic shears of the Jizera FG had a leading role in defining the subtle topography of the drainage system, regardless of the underlying lithology.

The broadest part of the palaeodrainage infill is located entirely on the Late Palaeozoic basin substratum, and a marked downstream narrowing of the axial palaeovalley occurs immediately at the contact point with the Saxothuringian Zone metamorphics and subordinate Variscan granitoids. The change in width of the palaeodrainage is interpreted as due to the difference in resistance to erosion between the Carboniferous clastics and the metamorphic basement. Importantly, the palaeodrainage strike shows no change within the Labe FZ where it crosses the sedimentary/metamorphic basement contact, implying a strong superimposed structural control by the N-S fault system.

\section{The Niederschöna Palaeovalley, Saxony}

The Niederschöna Palaeovalley is preserved as a chain of erosional outliers of fluvial to estuarine strata of Cenomanian age in the westernmost part of the Saxonian tip of the BCB (T. Voigt 1998). It was not a part of the analysis presented here, but in order to provide a complete picture of Cenomanian palaeodrainage evolution, the published data and interpretations are briefly discussed below.

Main morphological features and relationships to basement. - The palaeovalley is oriented roughly ENE, with a bend to the SW close to the Karsdorf Fault (Fig. 6), eroded into phyllites, orthogneisses of the Saxothuringian domain, and Late Palaeozoic volcanics. T. Voigt (1998) estimated the palaeovalley depth as 20 to $50 \mathrm{~m}$ and width ranging between 2 and $5 \mathrm{~km}$. Patchy occurrences of the fluvial Niederschöna Fm. such as that shown by Tröger (2003, his fig. 4) in the Elbe Valley near Pirna make it difficult to evaluate which structures may have directed the valley strike locally, but it clearly continued downstream toward the Lužice FZ.

Fluvial to estuarine infill. - The earliest Niederschöna Palaeovalley infill shows a succession of braided-river strata overlain by meandering-stream deposits and ultimately covered by tide-dominated estuarine strata, analogous to the palaeovalley fills in Bohemia. According to T. Voigt (in S. Voigt et al. 2008), most of the valley fill is probably of middle Cenomanian age, overlain by estuarine sandstones of early late Cenomanian age. As an alternative interpretation, early Cenomanian age was proposed for the oldest part of the palaeovalley fill, followed by a significant mid-Cenomanian hiatus (Tröger 2003 and references therein). In the interpretation of Tröger (2003, his fig. 2) the Niederschöna Fm. is considered partly coeval with the late early Cenomanian coastal facies of the Meissen Fm. preserved in the northwesternmost extremity of the BCB, making the transition to the North German Basin.

In the northern part of the Western PDS on the Czech territory, estuarine sandstones dominated the palaeovalley fills. Therefore, the fluvial succession underlying similar sandstone units in the Niederschöna Palaeovalley (Fig. 11) is considered older than most of the CEN 1-CEN 2 palaeovalley fills described here. The Niederschöna fluvial strata correspond either to the lowermost few metres of the Western PDS fill without clear marine indicators, or even to an earlier depositional episode not recorded in the other PDSs. Another alternative, with the Niederschöna Fm. interpreted as a more updip equivalent of the estuarine deposits at the base of the Western PDS near the Czech/German border, is considered less likely because of the topographic prominence of the Niederschöna Palaeovalley that was most probably deeper than the adjacent downstream end of the Western PDS.

Controls on palaeotopography. - The relicts of the Niederschöna Palaeovalley fill show a zigzag trace consisting of E-W or NNE-striking segments, probably corresponding to local metamorphic fabrics of the Saxothuringian basement ( $c f$. Konopásek et al. 2001 for analogies), alternating with segments striking northwest, parallel with the Karsdorf Fault and other Labe Group faults and fractures.

\section{Northern Palaeodrainage System}

The Northern PDS is a collective term for a series of roughly parallel, short, narrow palaeovalleys, all draining to the $\mathrm{N}$ and NE toward the Lužice FZ. The upstream limit of these palaeovalleys is located along or within the Ploučnice FZ. Metamorphic and igneous basement rocks of the Saxothuringian Zone prevail over Late Palaeozoic basin fills in the basement of this palaeodrainage system. Below, individual palaeovalleys are briefly described, with only the Ralsko Palaeovalley dealt with in more detail.

The Jetrichovice Palaeovalley. - A short (9 km) palaeovalley of a generally N-S trend is located near Jetřichovice (Valečka 1979) and extends toward the Lužice FZ into Saxony. This valley was a narrow depression (just $1-2 \mathrm{~km}$ in 
width), eroded into the Cadomian granites of the Lužice Granitoid Complex. Its infill, described by Valečka (1979) as fluvial, is characterized by several fining-upward, heterolithic successions that reach a maximum thickness of $25 \mathrm{~m}$. They probably represent tide-influenced fluvial and estuarine facies and correspond to CEN 2 and CEN 3 sequences (Fig. 15A, B). The palaeotopographic low still existed during the time of shallow-marine deposition of CEN 4 as documented by onlap of this unit on the palaeovalley slopes.

The Cvikov and Rynoltice palaeovalleys. - The Cvikov Palaeovalley trend follows roughly the eastern margin of the underlying Late Palaeozoic Česká Kamenice Basin and corresponds to an area of fluvial deposition reported by Steiner (1978). It covers a larger area than the neighbouring Jetrrichovice Palaeovalley. The preserved length of the axial valley, extending from the Lužice FZ in the North to the Ploučnice FZ in the South, is $c a 22 \mathrm{~km}$. The general trend of the Palaeovalley is roughly N-S, with some segments possibly striking northeast. The tributary valleys to the East follow the trend of the Labe FG. The infill corresponding to CEN 2 and CEN 3 sequences reaches $30 \mathrm{~m}$ in thickness.

The Rynoltice Palaeovalley shows a similar strike and infill, but is shorter - ca $10 \mathrm{~km}$. Its southern segment strikes more to the NE, in a similar way to the neighbouring Ralsko Palaeovalley.

The Ralsko Palaeovalley. - The Ralsko Palaeovalley was drilled by a large number of wells in the uranium mining district of Stráž pod Ralskem ( $c f$. Rutšek \& Kučera 1995, and references therein). Therefore, its morphology and relationship to basement fabric could be described in a greater detail than in other parts of the Northern PDS.

Main morphological features and relationships to basement. - The generalized axis of the Ralsko Palaeovalley strikes NE, at about a $30^{\circ}$ angle to the modern Stráž Fault (Fig. 6). In detail, however, it shows some segments having a nearly N-S strike resembling the Jizera FG, and short tributaries of a NW-SE strike, probably reflecting individual faults and fracture zones of the Labe FG. Especially the northeasternmost tributary, closest to the Lužice FZ, is markedly straight (Fig. 14A, B). The palaeovalley axis is $22 \mathrm{~km}$ long and the maximum thickness of its infill reaches $45 \mathrm{~m}$. In the northern part of the palaeovalley, underlain largely by phyllites and quartzites of the Krkonoše-Jizera Metamorphic Complex, its contours are about 50\% narrower than in the southern part, underlain largely by Late Palaeozoic clastics and volcanics of the Mnichovo Hradiště Basin. To the northwest, the palaeovalley was bordered by a flat palaeohigh formed by phyllites of the Krkonoše-Jizera Metamorphic Complex, whereas to the southeast lay an elevated region of the northern slope of the Bezděz Pala- eohigh, mostly formed by the Mnichovo Hradiště Basin fill (Fig. 13). The divide between the Northern and Central PDSs was located here, following the western limb of the Jizera FZ.

The general strike of the Ralsko Palaeovalley is similar to the strike of steeply dipping foliation of phyllites and quartzites of the Krkonoše-Jizera Metamorphic Complex, exposed northeast of the Lužice FZ (Fig. 15A; $c f$. Kozdrój et al. 2001). The relatively steep slopes of the valleys on metamorphic basement are therefore probably an effect of weathering and erosion along steep foliation planes and lithological gradients (phyllite/quartzite).

Fluvial to estuarine infill. - The infill of the Ralsko Palaeovalley and its tributaries generally resembles that of the Central PDS. Fluvial to estuarine strata reach a maximum thickness of $41 \mathrm{~m}$ and are typically composed of several fining-upward cycles, with a general superimposed trend of fining upward throughout the entire succession. In contrast to the Central PDS infill, breccias are abundant on the coarse end of the lithological range and commonly alternate with thick kaolinitic claystone horizons. In spite of physical separation from the preserved Central PDS infill, the well-log patterns and core allow correlations to be made between the Ralsko Palaeovalley infill and the CEN 1-CEN 3 sequences defined in the Central PDS. Strata equivalent to CEN 1 are completely devoid of marine plankton but tidal influence near the top of the fluvial succession correlative to CEN 2 has been detected in palynomorph assemblages. Heterolithic laminites interpreted as estuarine intertidal deposits occur near the top of CEN 2. CEN 3 is mostly represented by coarse-grained sandstones interpreted as subtidal channel fills.

The Starý Dub Palaeovalley. - Immediately west of the northwestern margin of the Central PDS, a palaeovalley only 1-2 km wide and of $c a 7 \mathrm{~km}$ preserved length, striking northeast, closely follows the edge of the Late Paleozoic Mnichovo Hradiště Basin. Its strike probably reflects the Ohře FG trend preserved in the basement fabric in this location. The facies succession in the palaeovalley fill is closely similar to the neighbouring Central PDS.

Controls on palaeovalley formation and filling, Northern $P D S$. - Overall, the orientation of the individual palaeovalleys suggests a strong structural control, dominated by structures of the Jizera and partly, Ohře FGs. The high percentage of breccias in the stratal succession is interpreted as due to short transport along a relatively steep profile compared to the Central and Western PDSs. In addition, a large part of the catchment of the Northern PDS developed on metamorphics and marginal, coarse-grained facies of the Late Palaeozoic extensional basins. Some of the kaolinitic claystone beds in cores are difficult to distinguish from the underlying, 
in-situ weathering profiles, again apparently due to short downstream transport in the small palaeovalleys. The short length and apparently higher gradient than in the neighbouring PDSs might indicate an involvement of a subtle uplift immediately prior to, or during deposition; it is, however, difficult to recognize geometric evidence for uplift in the stratigraphy along the valley dip profiles.

One significant implication of the palaeotopography and infill history of the Cenomanian palaeodrainage is that the present-day Stráž Fault which forms a tectonically prominent border of a part of the Tertiary Ohře Graben did not have an individual predecessor structure significantly expressed in the Cenomanian palaeotopography.

\section{Eastern Palaeodrainage System}

The preserved record of the Eastern PDS covers a much smaller area than the Central and Western PDSs, due to Cenozoic differential uplift and erosion in the southeastern part of the basin (Figs 13, 15C). In addition, episodes of uplift affected the palaeovalley fills already during the Cenomanian. Therefore, the reconstruction of the palaeodrainage is more tentative than in previous cases.

Main morphological features and relationships to basement. - The best preserved part of the Eastern PDS is a palaeovalley segment, ca $40 \mathrm{~km}$ long, striking N160E, with several minor tributaries on both the eastern and western sides. This contiguous palaeovalley segment was referred to as the Semanín-Malonín "depression" in earlier literature (Vajdík \& Vybíral 1973, Frejková \& Vajdík 1974). North of Semanín, the palaeovalley infill is not preserved because of pre-late Cenomanian erosion (see below, and Fig. 14B). A branching relict of a Cenomanian drainage, filled largely by tide-influenced deposits, corresponding to sequence CEN $\mathrm{C} 1$, is found $\mathrm{ca} 15 \mathrm{~km}$ further North near Potštejn. It is interpreted here as the most upstream part of the Eastern Trunk Palaeovalley (inset in Fig. 14B). The axis of the entire valley, reconstructed as over $70 \mathrm{~km}$ long, closely followed the western marginal fault of the underlying Late Palaeozoic Orlice Basin. This fault juxtaposes the Late Carboniferous to Permian clastics (Holub in Pešek et al. 2001) against the metamorphic basement representing the northern extension of the Polička Metamorphic Complex and interpreted as part of the Lugian Zone (Fig. 4; e.g., Schulmann et al. 2009). The downstream end of the palaeovalley, in Malonín area, was separated by a low-relief palaeohigh from another palaeovalley preserved as a relict infill in the southernmost part of the Blansko Graben and named the Blansko Palaeovalley (southern part of the "Kunštát-Blansko depression", Vajdík \& Vybíral 1973). Vajdík et al. (1978) hypothesized that the two palaeovalleys were connected along the axis of the underlying Boskovice Graben.
A minor relict of a narrow palaeovalley fill, thickening to the South but isolated by Cenozoic erosion from the rest of basin fill, is the Skutíčko Palaeovalley (Fig. 13; part of the "Rosice-Štěpánov depression" of Vajdík \& Vybíral 1973). It is inferred here that it may have connected with a valley that cut obliquely across the area of the Blansko Graben. The hypothetical valley axis connecting these two palaeovalley relicts was referred to as the Svratka Palaeovalley in Uličný et al. (2004), and follows the inferred direction of clastic input into the Blansko Graben area in Frejková \& Vajdík (1974, their fig. 11).

Further south of the preserved BCB fill, evidence of fluvial deposition of speculative Cenomanian age, preserved along a fracture network belonging to the Sázava FZ, was reported by Vít et al. (2003).

Fluvial to estuarine infill. - Sequence CEN A, represented by coarse-grained sandstones and conglomerates, with subordinate mudstone interbeds (Fig. 11) fills the deepest, axial part of the Eastern Trunk Palaeovalley and has a possible equivalent in the basal fluvial strata in the Blansko Palaeovalley. It is interpreted as braided stream deposits, deposited as the first phase of backfilling of the palaeodrainage. Sequence CEN B, interpreted as lower-gradient river with a high proportion of overbank deposition and a possible tidal influence in the southernmost part of the region, filled a broader area shown by the outline in Fig. 13. Sequences CEN C1 and C2 represent two further steps in the gradual flooding of the area, with relatively uniform thickness distribution in cross-valley sections (Fig. 14B). They comprise mud-dominated, inner-basin fill of a barred estuary (CEN C1) and an infill of a large, brackish embayment that covered most of the region to the east of the Nové Město-Holice Palaeohigh (CEN C2).

Frejková \& Vajdík (1974) and Frejková (1984), based on heavy mineral data, proved the southward direction of palaeoflow in the Eastern PDS. These studies showed that the lowermost valley-filling units received a significant portion of clastic material from the Orlice Basin Permian strata, whereas provenance from metamorphosed units located further northwest and northeast, especially the Zábřeh Metamorphic Complex, dominates in the overlying units. This is explained by covering of most of the Orlice Basin by Cenomanian deposits relatively soon after the onset of the drainage backfilling. The more northern occurrences of Permian clastics, in the Krkonoše Piedmont Basin and the Intra-Sudetic Basin, were located beyond the main drainage divide.

Later deposition in the region is associated with the onset of subsidence in previously elevated area to the Southwest of the Eastern Trunk Palaeovalley, with coeval tilting of the underlying blocks, and partial erosion of the palaeovalley fills North of Semanín. Locally, the Turonian Bílá Hora Fm. directly overlies the relicts of fluvial strata of the oldest se- 
quences (Fig. 14B). Hypr et al. (1982) associated the uplifted block with the "Kozlov Ridge" (as defined e.g., in Soukup et al. 1962), and this interpretation was adopted by Kanta (2000). The Kozlov Ridge, however, is a Cenozoic morphotectonic feature, considerably smaller than the area affected by tilting and erosion prior to, or during the early phase of, deposition of CEN D (Uličný et al. 2004). The kinematics of individual basement structures during the CEN D local uplift has not yet been fully resolved.

Controls on palaeotopography. - The strike of the Eastern Trunk Palaeovalley along the western edge of the Permian Orlice Basin suggests a combination of lithological contrast and basement structural control. The strike of the presumed marginal faults of the Orlice Basin differs slightly from the present-day fault framework that is dominated by NNW-trending border faults of Cenozoic half-grabens (referred to as "synclines"and "anticlines" in earlier geological literature, e.g., Č. Zahálka 1921; see overview in Soukup et al. 1962 and references therein). The modern Svitava River shows a small divergence from the strike of the axis of the Eastern Trunk Palaeovalley.

Whereas the dominant Sudetic FG controlled the axis of the Eastern Trunk Palaeovalley, tributaries to the west of it may have followed fractures of the Labe System, not detectable in present day geology after the Cenozoic tectonic reworking. Several N-S-directed basement faults, attributed to the Jizera FG, clearly helped to define the prominent drainage divide of the Holice-Nové Město Palaeohigh. Syndepositional activity of any of the faults during the fluvial infill phase is not proven.

\section{Discussion}

\section{Basement fault zones as an overriding control on drainage}

The PDSs within the sub-Cretaceous unconformity developed, to a varying extent, on all orogenic zones of the Variscan basement and concentrated, in particular, above the post-orogenic, Late Palaeozoic basin fills. Although the axes of the most important palaeovalleys follow either the Late Palaeozoic basin axes (Western and Central PDSs) or their borders with older basement units (Eastern PDS), they are never confined to the inherited Late Palaeozoic basin framework and cross both into and out of it. Almost all of the palaeovalleys that were traceable in the subsurface in sufficient length follow one of three principal structural trends in the basement: the Labe (and Sudetic), Jizera, or the Ohře FGs. In spite of the overall gentle relief of the peneplain, with the deepest valleys less than $90 \mathrm{~m}$ below the surrounding terrain, the dependence on three structural directions shows the superiority of the fault and fracture systems over lithological contrasts. This is demonstrated, for instance, in the Western PDS, where the downstream change from WSW-ENE to N-S alignment of the Western Trunk Palaeovalley occurs well within the Late Palaeozoic basin fill.

Attempting to classify the drainage patterns (Howard 1967) of the bedrock-confined palaeovalleys in a study based on an irregular borehole network is not as meaningful here as in high-resolution studies of Quaternary palaeovalley networks such as that by Menier et al. (2006). Many of the Bohemian Cenomanian palaeovalleys would fall into the linear longitudinal network type, with elements of rectangular to trellis networks (e.g., the Cvikov Palaeovalley) where the valleys cross faults oblique to their axes.

\section{Effects of basement lithology on the palaeodrainage}

Parts of the Late Palaeozoic basin fills formed broad, lowlying regions in the pre-Cenomanian peneplain, in which the fluvial to estuarine infills created palaeovalley fills of up to $30 \mathrm{~km}$ cross-valley width. This is in marked contrast to palaeodrainage segments developed on metamorphic or igneous Variscan basement that show significantly narrower palaeovalleys with steeper sides (Fig. 14A). In a map view, downstream broadening is observed where a palaeovalley crosses from pre-Carboniferous basement to a Permo-Carboniferous basin fill, and vice versa. The lower resistance of Late Palaeozoic basin fills to weathering and erosion is interpreted to have produced broader palaeovalleys with lower cross-valley relief, in a similar way to the examples in Menier et al. (2006). This uniformity of cross-valley relief is not an artifact of interpolation in areas of low borehole coverage, as shown by the lithology-dependent changes in valley width in the densely drilled Ralsko Palaeovalley.

\section{Structural control on intrabasinal drainage versus outlet streams}

In order to answer the question which of the basement fault systems had the most profound influence on the palaeodrainage orientation, it is useful to make the distinction between the intrabasinal PDSs and the ultimate trunk streams facilitating drainage out of the basin area (Fig. 10A), toward the NW and SE. While the former are represented by the palaeovalley fills within the basin, the latter are interpreted from larger-scale palaeogeographic considerations and a few small palaeovalley fills (Blansko Palaeovalley), with most of their record destroyed due to Cenozoic inversion, shearing and erosion at the basin margins ( $c f$. Ziegler 1990, Coubal 1990). Within the basin area, the palaeovalley fills show an influence of all three main structural trends, with the N-S Jizera FG followed by the greatest 
number and length of valley segments. The fact that the Labe Group faults are not followed by the trunk streams of the PDSs but only by some tributaries, can easily be explained by the fact that the intra-basinal streams followed general topographical slopes dipping toward the Lužice FZ (Western, Northern, and Central PDSs) and the Železné hory FZ (Eastern PDS). This effect alone may have favoured the alignment of streams with structures orientated roughly transverse to the basin-bounding faults. It is possible that weathering and erosion in the peneplain were simply preferentially concentrated in areas where the N-S faults and fractures were made prominent by pre-Cenomanian (mostly Permian?) activity. In addition, however, an incipient, subtle activity of some of the Jizera Group faults, not detectable with the present data coverage, may have contributed to their prominence in the palaeodrainage pattern.

Along the Lužice FZ, a fault-aligned outlet stream is interpreted to have drained the western part of the basin toward the North German Basin (see below for discussion of palaeogeographic context). Across the main drainage divide, the inferred Svratka Palaeovalley drained toward the Tethys along the Železné hory FZ (Fig.10).

\section{Directions of outward drainage and regional palaeogeographic evolution}

The Cenomanian drainage from the BCB toward the Tethyan realm, along structures of the Labe FG, has long been accepted by most workers (Krystek \& Samuel 1972; Frejková \& Vajdík 1974; Malkovský et al. 1974; Svobodová 1992, 1997; Uličný \& Čech in S. Voigt et al. 2008). The location of the outlet path to the Boreal realm, however, has remained problematic. Uličný et al. (2004) and Uličný \& Čech (in S. Voigt et al. 2008) inferred a possible outflow from the Central PDS toward the NE, into the North Sudetic Basin region (grey arrow in Fig. 10A), and hypothesized that this outward drainage was joined from the WNW by a stream that followed the Lužice FZ.

The recent completion of sequence-stratigraphic correlation in the western part of the basin brought evidence for tidal-estuarine conditions at the downstream end of the Western PDS during the time of sequences CEN 1-CEN 2 (Figs 11, 14A). The paralic deposition near the western end of the Lužice FZ at this time is in contrast with fully fluvial conditions of CEN 1 and a modest tidal influence in fluvial strata of CEN 2 at the downstream end of the Central PDS, about $80 \mathrm{~km}$ ESE along the Lužice FZ. This fact supports the hypothesis of a northwestward drainage by an outlet stream along the Lužice FZ, towards the North German Basin (Fig. 13), rather than a northeastward path to the North Sudetic Basin. The latter would be twice as long, would have to have traversed several major fault zones (e.g., the
Intra-Sudetic Fault) while keeping out of the Intra-Sudetic Basin with only a minor reported record of Cenomanian fluvial deposits in the Krzesów area ( $c f$. Radwański 1975). Most importantly, the northeastward course contradicts the distribution of fluvial $v s$. estuarine facies of CEN 1-2 age along the Lužice FZ.

Hypothetically, in the absence of data on palaeotopography north of the Lužice FZ, it could be argued that individual palaeovalleys might have continued directly across the Lužice FZ further to the NE, across the block of the Saxothuringian Zone in Western Sudetes that in the late Cenomanian became a long-term source area. Such an interpretation, however, would require a total inactivity and a lack of surface expression of the Lužice FZ, as well as a continuation of the regional slope further northeast beyond the trace of this fault zone. An outward drainage axis following the Lužice FZ to a lower-middle Cenomanian marine embayment in the Meissen area is considered more likely and is consistent with the lower Cenomanian age suggested for the Niederschöna Fm. by Tröger (1996, 2003). The late middle to early late Cenomanian age of this formation inferred by T. Voigt (1998) was based on extrapolation of approximate dating of the first occurrence of Complexiopollis pollen by Pacltová (1966), from localities upstream in the Western PDS. There, however, the first fluvial deposits are much younger (CEN 3-CEN 4) than the Niederschöna Palaeovalley fill, as documented here (Figs 11, 14A).

\section{Passive palaeodrainage filling versus active subsidence/uplift}

The maximum thicknesses of the palaeovalley fills along the Lužice FZ, after removal of deformation by late Cenomanian subsidence, are very similar, with minor discrepancies of less than 10 per cent between different PDSs (Fig. 14). These facts suggest a common base level control, both at the time of valley cutting and during filling. Together with backfilling documented in the Western and Eastern PDSs, this indicates that passive filling of shallow palaeorelief of the peneplain dominated in the entire basin area. Therefore, we interpret the long-term, stepwise eustatic rise characteristic of the Cenomanian stage (Hancock \& Kauffman 1979, Gale et al. 2002) to have been the main cause of the stepwise base-level rise that caused backfilling of valleys and a stepwise increase in marine influence on deposition.

The first episode of differential subsidence documented by a change in thickness of shallow-marine facies across the Labe FZ occurred in CEN 4 sequence (Fig. 14A, downdip of borehole RD-1 in cross-section D1). The case of the Brník Palaeovalley (Fig. 14A, cross-section S3b), however, indicates that, locally, the palaeostress conditions 
could have led to syn-depositional subsidence during the pre-CEN 4 fluvial deposition earlier in the middle Cenomanian.

Regardless of the lack of direct evidence for syndepositional activity in most of the individual faults associated with individual palaeovalleys, the general, basin-scale picture of the distribution of PDSs and palaeohighs suggests that a palaeostress field, similar in orientation to that of late Cenomanian and Turonian ( $c f$. Uličný et al. 2009), may have caused gentle warping that influenced the peneplain slopes and directions of surface drainage ( $c f$. Holbrook \& Schumm 1999, Schumm et al. 2000). It is suggested here that the very subtle asymmetric subsidence along the principal fault zones, during the early and middle Cenomanian expressed only by regional slopes, later became much more pronounced when in late Cenomanian an increase in strain rates led to formation of depocentres and adjacent source areas, with the principal depocentres essentially copying the locations of earlier palaeotopographic lows of the fluvial infill phase (Fig. 10).

\section{Summary}

The tectonic layout of the BCB played a dominant role in determining the orientation of palaeovalleys and the general palaeosurface slopes towards the basin-bounding faults. The distribution of basin-scale topographic lows was similar to distribution of depocentres during later depositional phases of late Cenomanian-Coniacian times.

While bedrock lithology had the subordinate effect of narrowing or broadening valleys on more $v s$. less resistant substratum, respectively, the locations and directions of palaeovalleys were strongly controlled by positions of inherited Variscan basement fault zones. The intrabasinal part of the palaeodrainage network followed the slopes toward the WNW-striking basin-margin faults of the Labe FG. Most palaeovalley axes followed the NNE- striking Jizera Group faults and fractures, prominent also in the alignment of modern streams in the area.

The outlet streams that drained the basin area are interpreted to have followed the Lužice FZ toward the Boreal province to the Northwest, and the Železné hory FZ toward the Tethyan province to the Southeast. At both the northwestern and southeastern ends of the BCB, shallow-marine or estuarine conditions are proven to have existed during the early Cenomanian. A major drainage divide, the Holice-Nové Město Palaeohigh, was located in the eastern part of the basin and followed the same strike as the modern North Sea/Black Sea drainage divide.

The onset of deposition by fluvial backfilling of the PDSs, followed by incremental marine flooding of the basin area throughout the Cenomanian, was caused mainly by the long-term, stepwise rise in global sea level. The earliest basin-scale episode of tectonic subsidence, accompanied by establishment of new source areas and by local intrabasinal uplifts, is documented from the late Cenomanian.

Direct evidence for syndepositional subsidence during the early to mid-Cenomanian fluvial to estuarine phase is very rare. It is inferred that subtle surface warping, mostly without detectable discrete faulting, was caused by the onset of the palaeostress regime that later, with further stress accumulation, led to the onset of subsidence in fault-bounded depocentres of the BCB and uplift of new source areas.

\section{Acknowledgements}

This research was supported by a Czech National Science Foundation (GAČR) grant, No. GA205/06/1823, to Lenka Špičáková, building partly on results of research under contract No. OG 9/02 from the Ministry of Environment of the Czech Republic, to David Uličný. The latter also supported acquisition of gravity maps. In addition, D.U. and L.S. acknowledge support of the AV 0Z30120515, and Marcela Svobodová AV 0Z30130516 research programmes of the Academy of Sciences of the Czech Republic. Acquisition of digital well-log data and core samples was made possible through cooperation with DIAMO, s.p. and the Czech Geological Survey - Geofond. We are particularly grateful for help with data acquisition to Pavel Veselý and Dana Čápová. Jaroslav Valečka has been helpful to our research for many years by providing his unpublished core documentation. Lenka Vacková and Monika Skopcová helped with drafting final versions of part of the diagrams. Stanislav Ulrich and Jiři Konopásek are thanked for valuable comments on the first draft of the paper. The paper benefited from constructive reviews by Pawel Aleksandrowski, Magdalena Scheck-Wenderoth, and, in particular, by Jiří Adamovič and Pavel Bosák. Bulletin editors Štěpán Manda and Jindřich Hladil, and Šárka Doležalová as the executive editor are thanked for all their help in the editorial process, but the responsibility for any remaining errors or omissions remains with the authors.

\section{Co-authors' affiliations}

Lenka Špičáková, Institute of Geophysics, Academy of Sciences of the Czech Republic, v. v. i., Boční II/1401, 14131 Praha 4, Czech Republic; spicka@ig.cas.cz•Radomír Grygar,V̌̌B - Technical University Ostrava, Institute of Geological Engineering, 17. listopadu, 70833 Ostrava - Poruba, Czech Republic; radomir.grygar@vsb.cz・Marcela Svobodová, Institute of Geology AS CR, v. v. i., Rozvojová 269, 16500 Praha 6, Czech Republic; msvobodova@gli.cas.cz•Stanislav Čech, Czech Geological Survey, Klárov 3, 11821 Praha 1, Czech Republic; stanislav.cech@geology.cz・Jiři Laurin, Institute of Geophysics, Academy of Sciences of the Czech Republic, v. v. i., Bočni II/1401, 14131 Praha 4, Czech Republic; laurin@ig.cas.cz. 


\section{References}

ALEKSANDROWSKi, P., KRYZA, R., MAZUR, S. \& ŻABA, J. 1997. Kinematic data on major Variscan fault and shear zones in the Polish Sudetes, NE Bohemian Massif. Geological Magazine 134, 727-39.

ANDRESEN, M.J. 1962. Paleodrainage patterns; their mapping from subsurface data, and their paleogeographic value. American Association of Petroleum Geologists Bulletin 46(3), 398-405.

ARTHAUd, F. \& MATTE, P. 1977. Late Paleozoic strike-slip faulting in Southern Europe and Northern Africa: Result of a right-lateral shear zone between Appalachians and Urals. Geological Society of America Bulletin 88(9), 1305-1320. DO] 10.1130/0016-7606(1977)88<1305:LPSFIS >2.0.CO;2

BeARD, B.L., MEDaris, L.G., Johnson, C.M., JelíneK, E., TONIKA, J. \& RICIPUTI, L.R. 1995. Geochronology and geochemistry of eclogites from the Mariánské Lázně Complex, Czech Republic: implications for Variscan orogenesis. Geologische Rundschau 86, 552-567.

DO] $10.1007 / \mathrm{s} 005310050024$

BLUM, M.D. \& TÖRNQVIST, T.E. 2000. Fluvial responses to climate and sea-level change: a review. Sedimentology 47 (supplement 1), 2-48. DOI 10.1046/j.1365-3091.2000.00008.x

BosÁK, P. 1995. Paleokarst of the Bohemian Massif in the Czech Republic: an overwiev and synthesis. International Journal of Speleology 24(1-2), 3-40.

BRANDMAYR, M., DALLMEYER, R.D., HANDLER, R. \& WALLBRECHER, E. 1995. Conjugate shear zones in the southern Bohemian Massif (Austria): implications for Variscan and Alpine tectonothermal activity. Tectonophysics 248(1-2), 97-116. DOI 10.1016/0040-1951(95)00003-6

COUBAL, M. 1990. Compression along faults: example from the Bohemian Cretaceous Basin. Mineralia Slovaca 22, 139-144.

ČECH, S., KLEIN, V., KŘÍŽ, J. \& VALEČKA, J. 1980. Revision of the Upper Cretaceous stratigraphy of the Bohemian Cretaceous Basin. Věstník Ústředního ústavu geologického 55, 277-296.

ČECH, S., HRADECKÁ, L., SVOBOdOVÁ, M. \& ŠvÁBENICKÁ, L. 2005. Cenomanian and Cenomanian-Turonian boundary in the southern part of the Bohemian Cretaceous Basin, Czech Republic. Bulletin of Geosciences 80(4), 321-354.

ČECH, S. \& VÁNĚ, V. 1989. K otázkám vývoje cenomanu a spodního turonu v Podkrušnohoří. Časopis pro mineralogii a geologii 33(4), 395-410.

CHÁB, J., STRÁNíK, Z. \& Elí́š, M. 2007. Geologická mapa České republiky. Česká geologická služba, Praha.

ChÁB, J., BReiter, K., FATKA, O., HLAdil, J., KalvodA, J., ŠIMŮNeK, Z., ŠTORCH, P., VAŠÍČEK, Z., ZAJíC, J. \& ZAPLETAL, J. 2008. Stručná geologie základu Českého masivu a jeho karbonského a permského pokryvu. 284 pp. Česká geologická služba, Praha.

ChAlOUPSKÝ, J. 1973. The basement of the Cretaceous and the Permo-Carboniferous of northern Bohemia. Geologische Rundschau 62, 581-594. DOI 10.1007/BF01840117

Chudomel, J., Cimbálník, V., JaKeš, O., Jihlavec, F., KLIMKOVÁ, V., NOVÁK, J., ONDRÁK, J., ŠUSTR, I. \& VAŠINOVÁ, J. 1983. Výzkum uhlonosných formaci Českého masívu - Zpráva o reflexně seismických a tíhových měřních v pánvích roudnické, mšenské, českokamenické, mnichovohradištské a podkrkonošské v letech 1981-1982. 176 pp. MS Geofyzika, Brno. Geofond P 53614, Praha.
DÖRR, W., Zulauf, G., Fiala, J., Franke, W. \& Vejnar, Z. 2002. Neoproterozoic to Early Cambrian history of an active plate margin in the Tepla-Barrandian unit - a correlation of $\mathrm{U}-\mathrm{Pb}$ isotopic-dilution-TIMS ages (Bohemia, Czech Republic). Tectonophysics 352, 65-85.

DO] 10.1016/S0040-1951(02)00189-0

ELIÁS̆, M. 1981. Facies and paleogeography of the Jurassic of the Bohemian Massif. Sborník geologických věd, Geologie 35, 75-144.

FRANKE, W. 2006. The Variscan orogen in Central Europe: construction and collapse, 334-343. In GEE, D.G. \& STEPHENSON, A.R. (eds) European Lithosphere Dynamics. Geological Society of London, Memoir 32.

FRANKE, W. \& ŻELAŹNIEWICZ, A. 2002. Structure and evolution of the Bohemian Arc, 279-293. In WINCHESTER, J.A., PharaOH, T.C. \& Verniers, J. (eds) Paleozoic Amalgamation of Central Europe. Geological Society of London, Special Publication 201.

FRANKe, W., HAAK, V., ONCKEN, O. \& TANNER, D. (eds) 2000. Orogenic processes: quantification and modelling in the Variscan Belt. 459 pp. Geological Society of London, Special Publication 179.

FREJKOVÁ, L. 1984. Petrografie sladkovodního cenomanu jv. okraje české křídové tabule. Sborník GPO 28, 87-112.

FREJKOVÁ, L. \& VAJDÍK, J. 1974. Příspěvek k paleogeografii a litologii cenomanských sedimentů v orlicko-žd'árské faciální oblasti. Sborník GPO 6, 5-28.

FRIČ, A. 1869. Palaeontologische Untersuchungen der einzelnen Schichten der bömischen Kreideformation. Die Perucer Schichten. Die Korycaner Schichten. Archiv für die naturwissenschaftliche Landes-Durchforschung von Böhmen I, 181-242.

FuCHS, G. \& MATURA, A. 1976. Die Geologie des Kristallins der südlichen Böhmischen Masse. Jahresberichte der geologischen Bundesanstalt 129, 41-49.

Gale, A.S., Hardenbol, J., Hathway, B., Kennedy, W.J., YOUNG, J.R. \& PHANSALKAR, V. 2002. Global correlation of Cenomanian (Upper Cretaceous) sequences: Evidence for Milankovitch control on sea level. Geology 30(4), 291-294. DOI 10.1130/0091-7613(2002)030<0291:GCOCUC >2.0.CO;2

GALLOWAY, W.E. 1989. Genetic stratigraphic sequences in basin analysis I: Architecture and genesis of flooding-surface bounded depositional units. American Association of Petroleum Geologists Bulletin 73, 125-142.

GREB, S.F. 1989. Structural controls on the formation of the sub-Absaroka unconformity in the U.S. Eastern Interior Basin. Geology 17, 889-892. DOI 10.1130/0091-7613(1989)017<0889:SCOTFO >2.3.CO;2

HANCOCK, J.M. \& KAUFFMAN, E.G. 1979. The great transgressions of the Late Cretaceous. Journal of the Geological Society 136, 175-186. DOI 10.1144/gsjgs.136.2.0175

HANZLÍKOVÁ, E. \& BOSÁK, P. 1977. Microfossils and microfacies of the Jurassic relict near Olomučany (Blansko district). Věstník Ústředního ústavu geologického 52, 73-79.

HERČ́́K, F., HERRMANN, Z. \& VALEČKA, J. 1999. Hydrogeologie české kř́lové pánve. Hydrology of the Bohemian Cretaceous Basin. 115 pp. MS Česká geologická služba, Praha.

HolbROOK, J. \& SCHUMM, S.A. 1999. Geomorphic and sedimentary response of rivers to tectonic deformation: a brief review and critique of a tool for recognizing subtle epeirogenic defor- 
mation in modern and ancient settings. Tectonophysics 305(1-3), 287-306. DOI 10.1016/S0040-1951(99)00011-6

Holub, V., KuKla, V. \& PraŽÁK, J. 1972. Vrt Se-1 Seletice. Závěrečná zpráva. 34 pp. Ústřední ústav geologický, Praha. Geofond P223067.

HoUŠA, V. 1991. Faciální členění př́ibřežních mořských sedimentů české křídy. Časopis Národního muzea, Řada př́rodovědná 156, 101-115.

HOWARD, A.D. 1967. Drainage analysis in geologic interpretation a summation. American Association of Petroleum Geologists Bulletin 51, 2246-2259.

HYPR, D., VybíRAL, J., ŠTos, P., HRUŠÁK, J. \& OHLídAlOVÁ, D. 1982. Závěrečná zpráva Semanín, Geologická část. 168 pp. Geologický průzkum Ostrava, n. p., závod Brno. MS Unigeo, Ostrava. Geofond FZ 5957, Praha.

JELEN, J. \& MALECHA, A. 1988. Zpráva o vývoji cenomanu na jižním Lounsku (II. etapa) s vyhodnocením prognóz jílovců mezi Jimlínem a Píštany. 38 pp. MS Ústř̌ední ústav geologický, Praha.

JERZYKIEWICZ, T. \& WoJEWODA, J. 1986. The Radków and Szczeliniec Sandstones: an example of giant foresets on a tectonically controlled shelf of the Bohemian Cretaceous Basin (Central Europe), 1-15. In KNIGHT, J.R. \& MCLEAN, J.R. (eds) Shelf sands and sandstones, Canadian Society of Petroleum Geologists Memoir 11.

JINDŘICH, V. 1971. New views in tectonic significance of platform sediments in the Bohemian Massif, Czechoslovakia. Geological Society of America Bulletin 82, 763-768. DO] 10.1130/0016-7606(1971)82[763:NVITSO]2.0.CO;2

KAMARÁD, L. \& MALKOVSKÝ, M. 1956. Železitý kaolinitický jílovec („bauxit“) v Motolském údolí v Praze. Časopis pro mineralogii a geologii 1, 8-14.

KANTA, J. 2000. Sedimentologie a sekvenční statigrafie perucko-korycanského souvrství v jihovýchodní části české kř́dové pánve mezi Litomyšli a Letovicemi. 89 pp. MSc. thesis, Charles University, Prague, Czech Republic.

KLEIN, V. 1957. Použití výsledků těžkých minerálů pro stratigrafii a paleogeografii cenomanu na Kouřimsku. Sborník Ústředního ústavu geologického, Oddíl geologický 24(1), 401-428.

KLEIN, V., MÜLLER, V. \& VALEČKA, J. 1979. Lithofazielle und paläogeographische Entwicklung des Böhmischen Kreidebeckens. Aspekte der Kreide Europas. IUGS Series A 6, 435-446.

Klein, V., HercogovÁ, J. \& ReJChrT, M. 1982. Stratigraphie, Lithologie und Paläontologie der Kreide im Elbe-Faziesgebiet. Sborník geologických věd, Geologie 36, 27-92.

KoDYM, O. 1923. Nejjižnější zbytky křídové v okolí pražském. Rozpravy České akademie věd, Třída matematicko-přírodovědecká 32(II/6), 1-15.

KonopÁseK, J. \& SCHUlmann, K. 2005. Contrasting Early Carboniferous field geotherms: evidence for accretion of a thickened orogenic root and subducted Saxothuringian crust (Central European Variscides). Journal of the Geological Society, London 162(3), 463-470. DOI 10.1144/0016-764904-004

KONOPÁSEK, J., SCHULMANN, K. \& LEXA, O. 2001. Structural evolution of the central part of the Krušné hory (Erzgebirge) Mountains in the Czech Republic - evidence for changing stress regime during Variscan compression. Journal of Structural Geology 23(9), 1373-1392.

DO1 $10.1016 / \mathrm{S} 0191-8141(01) 00003-7$
KoŠLER, J., AftAlion, M. \& BowES, D.R. 1993. Mid-Late Devonian plutonic activity in the Bohemian Massif - U-Pb zircon isotopic evidence from the Staré Sedlo and Mirotice gneiss complexes, Czech Republic. Neues Jahrbuch für Mineralogie, Monatshefte 9, 417-431.

Kossmat, F. 1927. Gliederung des variszischen Gebirgsbaues. Abhandlungen Sächsischen Geologischen Landesamts 1, 1-39.

KoUTEK, J. 1927. To the question of the depth of Jurassic sea at Brno. Časopis Vlasteneckého spolku muzejního v Olomouci 38, $1-5$.

Kozdró,, W., Cymerman, Z., KachlíK, V. \& Opletal, M. 2001. Karkonosze-Jizera Region. In KoZDróJ, W., KRENTZ, O. \& OPletal, M. Comments on the geological map LausitzJizera-Karkonosze. 1 : 100000.64 pp. Sächsiches Landesamt für Umwelt und Geologie, Freiberg; Państwowy Instytut geologiczny, Warszawa; Český geologický ústav, Praha.

KREJČÍ, J. 1865. O křídovém útvaru. Časopis Musea Království českého 39, 222-242.

Kroner, U., MANSY, J.-L., MAZUR, S., ALEKSANDROWSKi, P., HANN, H.P., HUCKRIEDE, H., LACQUEMENT, F., LAMARCHE, J., LEDRU, P., PhaRAOH, T.C. \& ZULAUF, G. 2008. Variscan tectonics, 599-664. In MCCANN, T. (ed.) Geology of Central Europe, Volume 1: Precambrian and Palaeozoic. The Geological Society, London.

KRYSTEK, I. \& SAMUEL, O. 1978. Výskyt kriedy karpatského typu

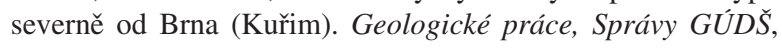
93-110.

Kumpera, O., BlažEK, J., Grygar, R. \& PeŠEK, J. 1986. Strukturně-geologická mapa ČSSR 1 : 200000 (list 04 - Náchod). Soubor účelových map k. p. Uranový průmysl Liberec. Ústřední ústav geologický, Praha.

KumPERA, O., ZEMAN, J., GRYGAR, R., KALENDOVÁ, J., ADAMusová, M., MÁtlová, E., Moupic, Z. \& STÁrkovÁ, I. 1988. Strukturně-geologická mapa ČSR 1 : 500000 . Účelová mapa k. p. Uranový průmysl Liberec. Ústřední ústav geologický, Praha.

LAURIN, J. \& ULIČNÝ, D. 2004. Controls on a shallow-water hemipelagic carbonate system adjacent to a siliciclastic margin: example from Late Turonian of Central Europe. Journal of Sedimentary Research 74, 697-717. DOI 10.1306/020904740697

LECKIE, D.A. 2008. Anatomy of an unconformity and its earliest overlying fill - the basinwide sub-Cretaceous unconformity of Western Canada Foreland Basin. 2008 GSA Annual Meeting in Houston, Texas USA, Geological Society of America Abstracts with Programs 40(6), 186.

LIPPOLT, H.J., HESS, J.C., HOLUB, V.M. \& PEŠEK, J. 1986. Correlation of Upper Carboniferous deposits in the Bohemian Massif (Czechoslovakia) and in the Ruhr district (FR Germany): evidence from Ar-40/Ar-39 ages of tuff layers. Zeitschrift der deutschen geologischen Gesellschaft 137, 447-464.

Malavieille, J., Guihot, P., Costa, S., LardeauX, J.M. \& GARDIEN, V. 1990. Collapse of the thickened Variscan crust in the French Massif Central: Mont Pilat extensional shear zone and St. Etienne Late Carboniferous basin. Tectonophysics 177(1-3), 139-149. DOI 10.1016/0040-1951(90)90278-G

MALKOVSKÝ, M. 1987. The Mesozoic and Tertiary basins of the Bohemian Massif and their evolution. Tectonophysics 137, 31-42. DOI 10.1016/0040-1951(87)90311-8

MalkovskÝ, M., Benešová, Z., ČAdeK, J., Holub, V., ChaloupskÝ, J., Jete, J., MÜller, V., MAŠín, J. \& TÁSLER, 
R. 1974. Geologie české křídové pánve a jejího podloži. 262 pp. Ústřední ústav geologický \& Academia, Praha.

Martinsen, O.J., RYSETH, A., HElland-HANSEN, W., FLESCHE, H., TORKILDSEN, G. \& IDIL, S. 1999. Stratigraphic base level and fluvial architecture: Ericson sandstone (Campanian), Rock Springs Uplift, SW Wyoming, USA. Sedimentology 46, 235-259. DOI 10.1046/j.1365-3091.1999.00208.x

MATĚJKA, A. 1921. Příspěvek k poznání křídového útvaru na listu Praha. Rozpravy České Akademie věd 31(II/6), 1-12.

MATĚJKA, A. 1936. Kapitola o kř́idě, 12-21. In ČEPEK, L. Vysvětlivky ke geologické mapě Československé republiky, list Kladno 3952. Knihovna Státního geologického ústavu Republiky československé 17.

Matte, P., Respaut, J.P., Maluski, H., LANCelot, J.R. \& BRUNEL, M. 1986. The Pays De Bray Fault, a premesozoic ductile dextral strike-slip-fault - Hercynian synmetamorphic deformation (320 Ma) of a Precambrian granite ( $570 \mathrm{Ma})$ in the borehole Pays De Bray 201 (Structure and Geochronology U/Pb and Ar-39/Ar-40. Bulletin de la Société géologique de France 2, 69-77.

Matte, P., Maluski, H., Rajlich, P. \& Franke, W. 1990. Terrane boundaries in the Bohemian Massif: Result of largescale Variscan shearing. Tectonophysics 177(1-3), 151-170. DO1 10.1016/0040-1951(90)90279-H

MATTERn, F. 1996. The Elbe zone at Dresden - a Late Paleozoic pull-apart intruded shear zone. Zeitschrift der Deutschen Geologischen Gesellschaft 147(1), 57-80.

MATTERN, F. 2001. Permo-Silesian movements between Baltica and Western Europe: tectonics and 'basin families'. Terra Nova 13, 368-375. DO1 10.1046/j.1365-3121.2001.00368.x

MAZUR, S. \& ALEKSANDROWSKI, P. 2001. The Tepla(?)/Saxothuringian suture in the Karkonosze-Izera massif, western Sudetes, central European Variscides. International Journal of Earth Sciences 90(2), 341-60. DOI 10.1007/s005310000146

MCCANN, T., KieRnOWSKI, H., KrAiner, K., VoZÁROVÁ, A., Peryt, T., Opluštil, S., Stollhofen, H., Schneider, J., WetZel, A., BOUlVAin, F., DusAr, M., TÖRÖK, A., HAAS, J., TAIT, J. \& KÖRNER, F. 2008. Permian, 531-598. In MCCANN, T. (ed.) Geology of Central Europe, Volume 1: Precambrian and Palaeozoic. The Geological Society, London.

Menier, D., ReYnaud, J.-Y., Proust, J.-N., Guillocheau, F., GueNNOC, P., BONNET, S., TESSIER, B. \& GOUBERT, E. 2006. Basement control on shaping and infilling of valleys incised at the southern coast of Brittany, France, 37-55. In DALRYMPLE, R.W., LECKIE, D.A. \& TILLMAN, R.W. (eds) Incised valleys in time and space. Society of Economic Paleontologists Mineralogists Special Publication 85.

MLČOCH, B. (ed.) 2001. Výzkum krystalinických formací v hlubokých strukturách podloži Doupovského komplexu a jeho širšiho okolí. 122 pp. Závěrečná zpráva úkolu MŽP (VaV 630/1/00), MS Český geologický ústav, Praha. Geofond P101840, Praha.

OGG, J.G., AgTERBERG, F.P. \& GRAdSTEIN, F.M. 2004. The Cretaceous Period, 344-383. In GRAdSTEIN, F.M., OGG, J. \& SMITH, A. (eds) A Geologic Time Scale 2004. Cambridge University Press, Cambridge.

PaCltovÁ, B. 1966. Pollen grains of angiosperms in the Cenomanian Peruc Formation in Bohemia. The Paleobotanist 15(1-2), 52-54.
PACLTOVÁ, B. 1971. Palynological study of Angiospermae from the Peruc Formation (?Albian-Lower Cenomanian) of Bohemia. Sborník Ústředního ústavu geologického, P 13, 105-141.

PACLTOVÁ, B. 1977. Cretaceous Angiosperms of Bohemia - Central Europe. Botanical Review 43(1), 128-142.

DOI $10.1007 / \mathrm{BF} 02860851$

PASSER, M. 1967. Cenomanské jílovce, uhlírsko-janovická a černokostelecká oblast, surovina: žáruvzdorné jíly. 68 pp. MS Geoindustria, Praha. Geofond P020777, Praha.

PAŠEK, J. \& URBAN, M. 1990. The tectonic evolution of the Plzeň basin (Upper Carboniferrous, West Bohemia): a review and reinterpretation. Folia Musei rerum naturalium Bohemia occidentalis, Geologica 32, 3-56.

PEŠEK, J. (ed.) 2001. Geologie a ložiska svrchnopaleozoických limnických pánví České republiky. 243 pp. Český geologický ústav, Praha.

Pitra, P., BurG, J.P. \& Guiraud, M. 1999. Late Variscan strike-slip tectonics between the Tepla-Barrandian and Moldanubian terranes (Czech Bohemian Massif): petrostructural evidence. Journal of the Geological Society 156(5), 1003-1020. DOI 10.1144/gsjgs.156.5.1003

PlinT, A.G., MCCARTHY, P.J. \& FACCINI, U.F. 2001. Nonmarine sequence stratigraphy: Updip expression of sequence boundaries and systems tracts in a high-resolution framework, Cenomanian Dunvegan Formaton, Alberta Foreland Basin, Canada. American Association of Petroleum Geologists Bulletin 85, 1967-2001.

PosAmentieR, H.W. \& ALlen, G.P. 1999. Siliciclastic sequence stratigraphy: concepts and applications. $210 \mathrm{pp}$. Society of Economic Paleontologists and Mineralogists Concepts in Sedimentology and Paleontology 7. Tulsa.

POTTER, P.E. 1978. Significance and origin of big rivers. Journal of Geology 86, 13-33.

RADWAŃSKI, S. 1975. Kreda Sudetów środkowych w świetle wyników nowych otworów wiertniczych. Biuletyn Instytutu geologicznego 287, 5-59.

RAJCHL, M., ULIČNÝ, D. \& MACH, K. 2008. Interplay between tectonics and compaction in a rift-margin, lacustrine delta system: Miocene of the Eger Graben, Czech Republic. Sedimentology 55, 1419-1447. DOI $10.1111 / \mathrm{j} .1365-3091.2008 .00951 . x$

RAJCHL, M., ULIČNÝ, D., GRYGAR, R. \& MACH, K. 2009. Evolution of basin-fill architecture in an incipient continental rift: the Cenozoic Most Basin, Eger Graben, Central Europe. Basin Research 21, 269-294. DOI 10.1111/j.1365-2117.2008.00393.x

RUTŠEK, J. \& KUČERA, M. 1995. Geologická charakteristika křídových sedimentů, 128 pp. In RUTŠEK, J. (ed.) Závěrečné zpracování prací Uranového pri̊zkumu v české kř́dové pánvi za léta 1959-1990, Diamo, s. p., Stráž pod Ralskem. 133 pp. Geofond P098200, Praha.

SCHECK, M., BAYER, U., OTTO, V., LAMARCHE, J., BANKA, D. \& PHARAOH, T. 2002. The Elbe Fault System in North Central Europe - a basement controlled zone of crustal weakness. Tectonophysics 360, 281-299.

DOI 10.1016/S0040-1951(02)00357-8

SCHUlmanN, K., KONOPÁSEK, J., JANOUŠEK, V., LEXA, O., LARDEAUX, J.P., EDEL, J.-B., ŠTÍPSKÁ, P. \& UlRICH, S. 2009. An Andean type Palaeozoic convergence in the Bohemian Massif. Comptes Rendus Geoscience 341(2-3), 266-286. DOI 10.1016/j.crte.2008.12.006 
SChulMANN, K., LeXA, O., ŠTíPSKÁ, P., RACEK, M., TAJČMANOVÁ, L., KONOPÁSEK, J., EdEL, J.B., PESCHLER, A. \& LEHMANN, J. 2008. Vertical extrusion and horizontal channel flow of orogenic lower crust: key exhumation mechanisms in large hot orogens? Journal of Metamorphic Geology 26, 273-297. DOI 10.1111/j.1525-1314.2007.00755.x

SCHUMM, S.A. \& ETHRIDGE, F.G. 1994. Origin, evolution and morphology of fluvial valleys, 11-27. In DALRYMPLE, R.W., BOYD, R. \& ZAITLIN, B.A. (eds) Incised Valley Systems. Society of Economic Paleontologists Mineralogists Special Publication 51.

SCHUMm, S.A., Dumont, J.F. \& HolDBROOK, J.M. 2000. Active tectonics and alluvial rivers. 275 pp. Cambridge University Press, Cambridge.

SIEVER, R. 1951. The Mississippian-Pennsylvanian unconformity in southern Illinois. American Association of Petroleum Geologists Bulletin 35(3), 542-581.

SLAVÍK, F. 1922. O pisolitických rudách železných s příměsí bauxitovou v české křídě. Rozpravy České akademie věd a umění, Tř́da II (matematicko-př́rodovědecká) 31(3), 1-14.

SOUKUP, J. 1954. Ložiska cenomanských jílovců v Čechách a na Moravě, část II. Geotechnica 18, 1-179.

SOUKUP, J., DVOŘÁK, J. \& MALECHA, A. 1962. Křídový útvar. Přehled oblasti, faciálních a stratigrafických jednotek, tektonických poměru křídy, 145-153. In SvOBODA, J. (ed.) Vysvětlivky k prehehledné geologické mapě ČSSR 1:200 000, M-333-XXIII Česká Třebová. Nakladatelství ČSAV, Praha.

ŠPAČEK, P., SÝKOROVÁ, Z., PAZdírková, J., ŠVANCARA, J. \& HAVÍR̆, J. 2006. Present-day seismicity of the south-eastern Elbe Fault System (NE Bohemian Massif). Studia Geophysica et Geodaetica 50, 233-258. DOI 10.1007/s11200-006-0014-Z

ŠPIČÁKOVÁ, L. 1999. Fluviální sedimenty jihozápadního okraje české kř́dové pánve, zákonitosti jejich rozšíření v čase a prostoru. 139 pp. Ph.D. thesis, Univerzita Karlova, Praha.

ŠPIČÁKOVÁ, L., UliČNÝ, D. \& KoudELKOVÁ, G. 2000. Tectonosedimentary evolution of the Cheb Basin (NW Bohemia, Czech Republic) between Late Oligocene and Pliocene: a preliminary note. Studia Geophysica et Geodaetica 44, 556-580. DO1 10.1023/A:1021819802569

STEINER, J. 1978. Geologická charakteristika křídy v severovýchodní části lužické faciální oblasti. Sborník Severočeského musea, Př́rodní vědy 10, 101-123.

STÖRR, M., KUŽVART, M. \& NEUŽIL, J. 1978. Genesis of the weathering crusts of the Bohemian Massif. Schriftenreihe den geologischen Wissenschaften 208, 170-281.

STRÁNÍK, Z., BubíK, M., ČECH, S. \& ŠVÁBENICKÁ, L. 1996. The Upper Cretaceous in South Moravia. Věstník Českého geologického ústavu 71, 1-30.

SUESS, F.E. 1912. Die moravischen Fenster und ihre Beziehung zum Grundgebirge des Hohen Gesenkes. Denkschriften der kaiserlichen Akademie der Wissenschaften, mathematisch-naturwissenschaftlichen Klasse 83, 541-631.

SUESS, F.E. 1926. Intrusionstektonik und Wandertektonik im variszischen Grundgebirge. 268 pp. Verlag von Gebrüder Borntraeger, Berlin.

SVOBODA, J. et al. 1964. Regionální geologie ČSSR. Díl I. Český masív, sv. 2. Algonkium-kvartér. 543 pp. Nakladatelství ČSAV, Praha.

SvoBodovÁ, M. 1992. Earliest Upper Cretaceous palynomorphs of basal (transgressive) strata in the Blansko Graben (Moravia,
Czechoslovakia), 313-322. In EDER-Kovar, J. (ed.) Proceedings of the Pan-European Palaeobotanical Conference Vienna, 19-23 September 1991. Museum of Natural History, Vienna.

SVOBODOVÁ, M. 1997. Mid-Cretaceous palynomorphs from the Blansko Graben (Czech Republic): affinities to both Tethyan and Boreal bioprovinces. Proceedings $4^{\text {th }}$ EPPC. Mededelingen Nederlands Instituut voor Toegepaste Geowetenschapen TNO 58(1997), 149-156.

SvobodovÁ, M. \& BRENNER, G.J. 1999. Correlation of Mid-Cretaceous plant microfossils from the Raritan Formation of the Atlantic Coastal Plain with the Peruc-Korycany Formation of the Blansko Graben. Acta Palaeobotanica, Supplement 2, 199-209.

TÁSLER, R., CHALOUPSKÝ, J., KUKAL, Z., PRAŽÁK, J. \& SLAVÍK, J. 1984. Vrt DB-1. 34 pp. MS Ústřední ústav geologický, Praha. Geofond P47962, Praha.

TÁsler, R., Slavík, J. \& Chaloupský, J. 1986. Vrt Sč-1. Závěrečná zpráva. 39 pp. MS Ústřední ústav geologický, Praha. Geofond P53468, Praha.

TRÖGER, K.-A. 1996. The Upper Cretaceous of Saxony in the framework of the European Cretaceous development. Mitteilungen der Geologischen-paläontogischen Institut der Universität zu Hamburg 77, 95-104.

TRÖGER, K.-A. 2003. The Cretaceous of the Elbe Valley in Saxony (Germany) - a review. Carnets de Géologie, article 2003/03 (CG2003_A03_KAT).

ULIČNÝ, D. 2005. Geologická interpretace vybraných reflexně seismických profilů, 145-164. In NOVOTNÝ, M., BROŽ, M., Hrubcová, P., HubATKA, F., KAROUSOVÁ, O., RŮŽEK, B., ŠPAČEK, P., ŠPIČÁK, A., ŠVANCARA, J. \& ULIČNÝ, D. Závěrečná zpráva za projekt č. VaV/630/3/02 SLICE - Seismic Lithospheric Investigation of Central Europe. 213 pp. MS Geofyzikální ústav AVČR, Praha. Unpublished report, Ministry of Environment of the Czech Republic. Geofond P113039, Praha.

ULIČNÝ, D., ČECH, S. \& GRYGAR, R. 2003a. Tectonics and depositional systems of a shallow-marine, intra-continental strike-slip basin: exposures of the Český Ráj region, Bohemian Cretaceous Basin. Geolines 16, 133-148.

ULIČNÝ, D., HLADÍKOVÁ, J., ATTREP, M., ČECH, S., HRADECKÁ, L. \& SvobodOVÁ, M. 1997a. Sea-level changes and geochemical anomalies across the Cenomanian-Turonian boundary: Pecínov quarry, Bohemia. Palaeogeography, Palaeoclimatology, Palaeoecology 132, 265-285.

DOI 10.1016/S0031-0182(97)00055-2

UliČNÝ, D., KVAČEK, J., SvOBODOVÁ, M. \& ŠPIČÁKOVÁ, L. 1997b. High-frequency sea-level fluctuations and plant habitats in Cenomanian fluvial to estuarine succession: Pecínov quarry, Bohemia. Palaeogeography, Palaeoclimatology, Palaeoecology 136, 165-197. DOI 10.1016/S0031-0182(97)00033-3

ULIČNÝ, D., LAURIN, J. \& ČECH, S. 2009. Controls on clastic sequence geometries in a shallow-marine, transtensional basin: the Bohemian Cretaceous Basin, Czech Republic. Sedimentology 56, 1077-1114. DOI 10.1111/j.1365-3091.2008.01021.x

ULIČNÝ, D., MARTÍNEK, K. \& GRYGAR, R. 2002. Syndepositional Geometry and Post-Depositional Deformation of the Krkonoše Piedmont Basin: A Preliminary Model. Geolines 14, 101-102.

ULIČNÝ, D. \& ŠPIČÁKOVÁ, L. 1996. Response to high frequency sea-level change in a fluvial to estuarine succession: Cenomanian paleovalley fill, Bohemian Cretaceous Basin, 247-268. 
In Howell, J.A. \& AitKen, J.F. (eds) High Resolution Sequence Stratigraphy: Innovations and Applications. Geological Society of London, Special Publication 104.

ULIČNÝ, D., ŠPIČÁKOVÁ, L., ČECH, S. \& LAURIN, J. 2003b. Response of depositional style of an intra-continental strike-slip basin to changes in relative activity of basement fault zones: Cenomanian of the Bohemian Cretaceous Basin, Czech Republic. Abstract Book, $22^{\text {nd }}$ International Association of Sedimentologists Meeting of Sedimentology, Opatija, Croatia 2003, 213.

UliČNÝ, D., ŠPIČÁKOVÁ, L., TASÁRYOVÁ, Z., ČECH, S., HRADECKÁ, L., ŠVÁBENICKÁ, L., GRYGAR, R. \& SVOBODOVÁ, M. 2004. Stratigrafická architektura cenomanu české kř́dové pánve: vztahy sedimentárních systémů a reaktivace struktur podloži kř́dy. Závěrečná zpráva studie odboru geologie Ministerstva životního prostředí ČR $O G$ - 9/02. 19 pp. MS Geofyzikální ústav AVČR, Praha. Geofond P114123, Praha.

VACHTL, J. 1950. Ložiska cenomanských jílovců v Čechách a na Moravě. Část I. Okolí Měcholup, Třeskovic, Markvarce, Domoušic u Kounova v západních Čechách. Geotechnica 10, 1-72.

VACHTL, J. 1962. Ložiska cenomanských jílovců v Čechách a na Moravě. Část III - Vyšehořovicko, Černokostelecko a okolí Uhliřských Janovic. Geotechnika 31, 1-103.

VACHTL, J. 1964. Poznámky k tektogenezi středočeských permokarbonských depresí. Zprávy o geologických výzkumech $v$ roce $1963,115-117$.

Vachtl, J., Malecha, A., PeloušeK, J., Pelikán, V., FRAnČE, J. \& RYŠAVÝ, P. 1968. Ložiska cenomanských jílovců v Čechách a na Moravě. Díl IV. Geotechnica 32, 1-162.

VAJDÍK, J., JURENKOVÁ, M., LAVRINĚNKO, M., LITZMANOVÁ, L., POSPÍŠIL, Z., ŠAFRÁNEK, V., STAŇKOVÁ, J. \& ŽIVOTSKÝ, J. 1978. Východočeská a západomoravská kř́da. Závěrečná zpráva. MS Unigeo Ostrava, závod Brno. Geofond P035382, Praha.

VAJDÍK, J. \& VYBÍRAL, J. 1973. Průzkum ložisek žáruvzdorných jílovců v areálu západomoravské a východočeské kř́ídy. Sborník GPO 2, 27-50.

VALEČKA, J. 1975. Litologie, cyklická stavba a geneze bazálních svrchnokřídových sedimentů západně od Děčína. Časopis pro mineralogii a geologii 18, 379-391.

VALEČKA, J. 1979. Paleogeografie a litofaciální vývoj severozápadní části české křídové pánve. Sborník geologických věd, Geologie 33, 47-81.

VALEČKA, J., ČECH, S., HERRMANN, Z., KAAS, A. \& PRAŽÁK, J. 2003. Tectonic map of the Bohemian Cretaceous Basin, 91 pp. In HerČíK, F., HerrmanN, Z. \& VAleČKA, J. (eds) Hydrogeology of the Bohemian Cretaceous Basin. Czech Geological Survey, Praha.

VALEČKA, J. \& SKOČEK, V. 1991. Late Cretaceous lithoevents in the Bohemian Cretaceous Basin. Cretaceous Research 12, 561-577. DOI 10.1016/0195-6671(91)90031-7

VAn Wagoner, J.C., Posamentier, H.W., Mitchum, R.M., VAIL, P.R., SARG, J.F., LOUTIT, T.S. \& HARDENBOL, J. 1988. An overview of fundamentals of sequence stratigraphy and key definitions, 39-44. In WILGUS, C.K., HASTINGS, B.S., KENDALl, C.G.S.C., POSAMENTIER, H.W., ROSS, C.A. \& VAN WAGONER, J.C. (eds) Sea Level Changes: An Integrated Ap- proach. Society of Economic Paleontologists and Mineralogists Special Publication 42.

VeJluPeK, M., ČejChanová, B., DudeK, A., Hercogová, J., Jetel, J., Klein, V., KoMÁReK, J. \& MAREK, V. 1967. Vrt Le-1 Luštěnice. 38 pp. MS Ústřední ústav geologický. Geofond P19903, Praha.

Vít, J., Petrová, P. \& Otava, J. 2003. Paleontological and sedimentological evidence of NW-SE striking faults in the northern vicinity of Brno. Geolines 16, 108-109.

Voigt, S., Wagreich, M., SurlyK, F., WalaszczyK, I., UliČNÝ, D., ČECH, S., VOIGT, T., WieSE, F., WilmSEN, M., Niebehr, B., Reich, M., Funk, H., Michalík, J., JaGt, J.W.M., FElder, P.J. \& SCHUlP, A.S. 2008. Cretaceous, 923-997. In MCCANN, T. (ed) Geology of Central Europe, Volume 2: Mesozoic and Cenozoic. The Geological Society, London.

VoIGT, T. 1994. Faziesentwicklungen und Ablagerungssequenzen am Rand eines Epikontinentalmeeres - Die Sedimentazionsgeschichte der Sächsischen Kreide. 133 pp. Ph.D. thesis, Bergakademie Freiberg, Germany.

VOIGT, T. 1998. Entwicklung und Architektur einer fluviatilen Talfüllung - die Niederschöna Formation im Sächsischen Kreidebecken. Abhandlungen des Staatlichen Museums für Mineralogie und Geologie in Dresden 43/44, 121-139.

ZAHÁLKA, B. 1911. Křídový útvar v západním Povltaví. Pásmo I a II. Věstník Královské České společnosti nauk, Tř́da matematicko-přirodovědecká, 1-87.

ZAHÁlKA, B. 1950. Exogyrová lavice křídová nad Blanskem. Věstník Královské České společnosti nauk, Tř́da matematicko-přírodovědecká 20,1-10.

ZAHÁLKA, Č. 1921. Východočeský útvar kř́dový. Část severní s Kladskem a Slezskem. Ministerstvo školství a národní osvěty, 105 pp. Roudnice.

ZAITLIN, B.A., DALPYMPLE, R.W. \& BOYD, R. 1994. The stratigraphic organization of incised-valley systems associated with relative sea-level change, 45-60. In DALPYMPLE, R.W. \& ZAitlin, B.A. (eds) Incised Valley Systems. Society of Economic Paleontologists Mineralogists Special Publication 51.

ŽÁK, J., HOLUB, F.V. \& VERNER, K. 2005. Tectonic evolution of a continental magmatic arc from transpression in the upper crust to exhumation of mid-crustal orogenic root recorded by episodically emplaced plutons: the Central Bohemian Plutonic Complex (Bohemian Massif). International Journal of Earth Sciences 94(3), 385-400. DOI 10.1007/s00531-005-0482-3

ZELENKA, P. 1987. Litofaciální vývoj křídových uloženin v Praze a okolí. Sborník geologických věd, Geologie 42, 89-112.

ZIEGLER, P.A. 1990. Geological Atlas of Western and Central Europe. 239 pp. Shell Internationale Petroleum Maatschappij, The Hague.

ZIEGLER, P.A. \& DEZES, P. 2007. Cenozoic uplift of Variscan Massifs in the Alpine foreland: Timing and controlling mechanisms. Global and Planetary Change 58(1-4), 237-269. DOI 10.1016/j.gloplacha.2006.12.004

ZVEJŠKA, F. 1953. Ke stratigrafii a tektonice kř́dových vrstev v blanenském prolomu. Spisy Př́rodovědecké fakulty Masarykovy univerzity G3 351, 1-24. 